\title{
$T_{0}=$ tangan \\ MASTER

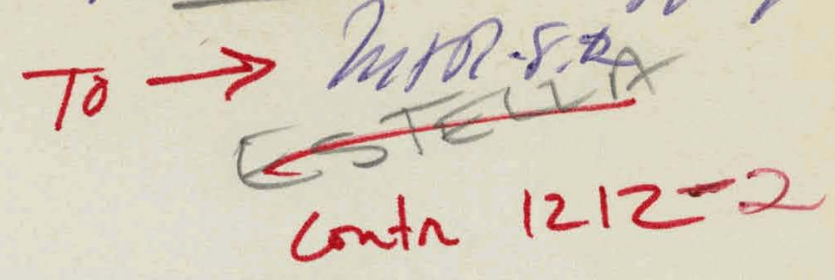 \\ DEPARTMENT OF MECHANICAL ENGINEERING
}

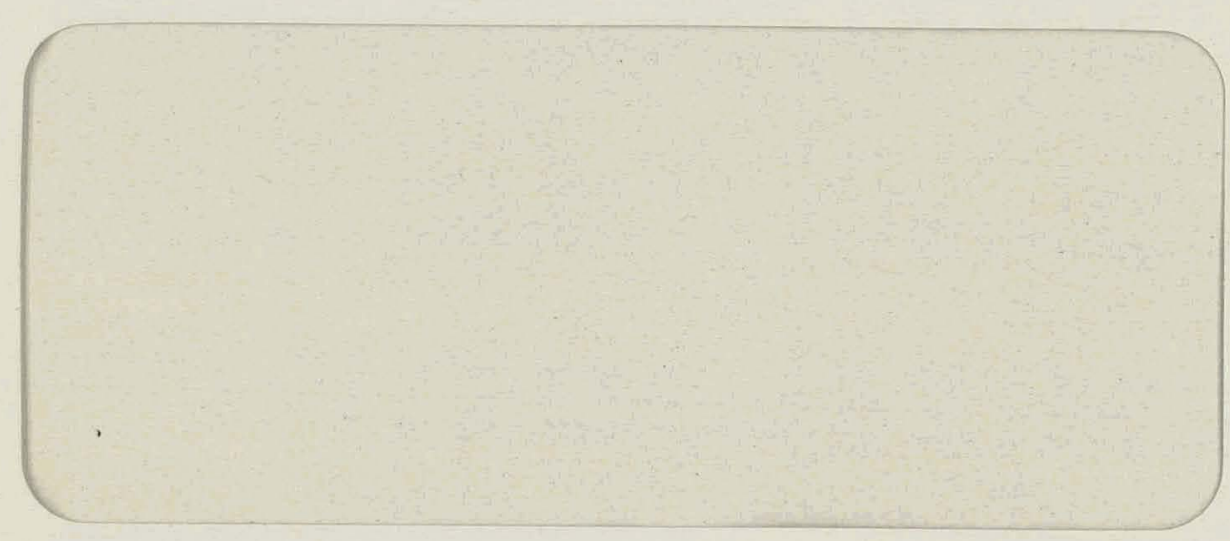

School of Engineering and Environmental Design

\section{UNIVERSITY OF MIAMI}

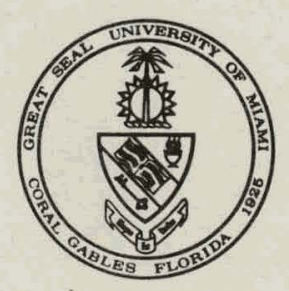

Coral Gables, Florida 33124 


\section{DISCLAIMER}

This report was prepared as an account of work sponsored by an agency of the United States Government. Neither the United States Government nor any agency Thereof, nor any of their employees, makes any warranty, express or implied, or assumes any legal liability or responsibility for the accuracy, completeness, or usefulness of any information, apparatus, product, or process disclosed, or represents that its use would not infringe privately owned rights. Reference herein to any specific commercial product, process, or service by trade name, trademark, manufacturer, or otherwise does not necessarily constitute or imply its endorsement, recommendation, or favoring by the United States Government or any agency thereof. The views and opinions of authors expressed herein do not necessarily state or reflect those of the United States Government or any agency thereof. 


\section{DISCLAIMER}

Portions of this document may be illegible in electronic image products. Images are produced from the best available original document. 


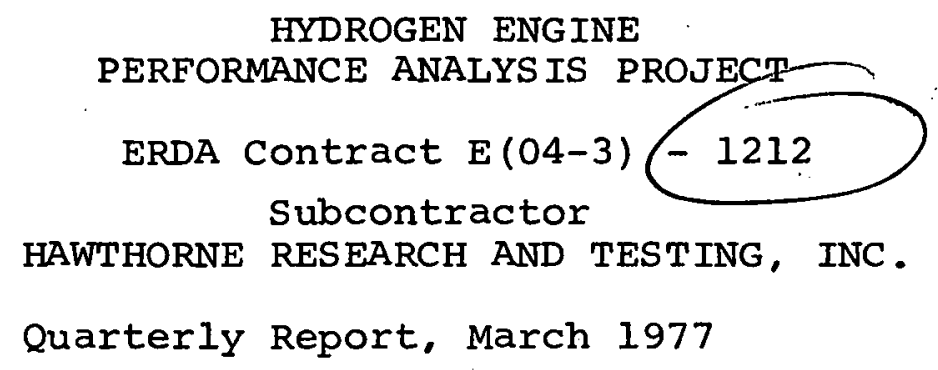

Robert R. Adt, Jr. University of Miami

Michael R. Swain John M. Pappas Hawthorne Research and Testing, Inc. $\therefore$ $\therefore, \therefore 6$ ACO3-77CS51212

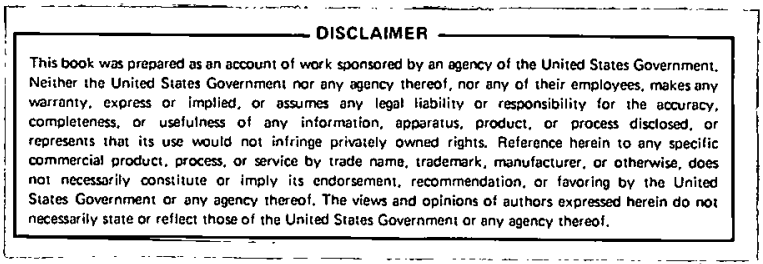

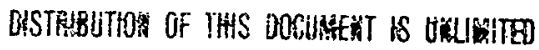


Page No.

I.

INTRODUCTION

II.

DISCUSSION OF APPROACHES AND ACCOMPLISHMENTS .

A. FLASHBACK • • • • •. . . • • • • • • • , 1

A-1 THERMAL CHARACTERISTICS OF

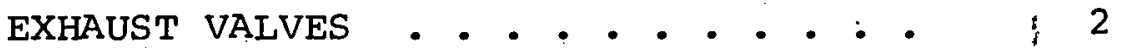

A-2 RES IDUALS, OIL ENTRAINMENT AND FLASHBACK •. •. . . . . . . 5

A-3 TIMED INDUCTION AND FLASHBÄCK • • • : 7

B CAMSHAFT SELECTION . . . . . . . . . . 8

C. TECHNIQUE FOR MEASURING EGR..$\quad \cdot \quad \cdot \quad \cdot \quad \cdot \quad 9$

D. STEADY-STATE DIFFUSION (SWIRL) MODEL . . . 13

D-1 ANALYSIS . . . . . . . . . . . 14

D-2 ASSUMPTIONS AND APPROXIMATIONS - , SUMMARY . . . . . . . . . . . . . 18

D-3 NUMERICAL EXAMPLES . . . . . . . 19

D-4 DISCUSSION . . . . . . . . . 20

E. FUEL AND AIR FLOW RATE MEASUREMENTS . . . 21

E-1 FUEL FLOW METER . . . . . . . . . . : 21

E-2 AIR FLOW METER . . . . . . . . . 22

F. SOLID STATE LOGIC IGNITION INTERRUPTER . . . 22

G. ENGINE BREAK IN . . . . . . . . . . . . 23

H. ENGINE OIL (LUBRICANT) . . . . . . . . . 23

I. CARBURETION SYSTEMS . . . . . . . . . - 23

J. OXIDES OF NITROGEN MEASUREMENTS . . . . . 23

K. OTHER CONS IDERATIONS . . . . . . . . . . . . 24

I. EQUIPMENT RECFTIVFR OR CONSTRUCTED - . . . 24 


\section{TABLE OF CONTENTS (cont.)}

Page No.

II. M. EQUIPMENT ON ORDER . . . . . . . . . . .

III. CONSULTATION ( $\mathrm{H}_{2}$ ENGINE TECHNOLOGYEFF IC IENCY-CONF IGURATION) . . . . . . . . •

IV REFERENCES

LIST OF TABLES 


\section{INTRODUCTION}

The objective of this project is to address the problems identified in the literature and in the project proposal [1] * in order to obtain the data-base covering performance, operational characteristics and emissions essential for making a rational decision regarding the selection and design of: prototype hydrogen-fueled, air-breathing engines capable of being manufactured for general automotive use. The project program plan calls for investigation of pre-intake valve closing fuel ingestion (Pre IVC) hydrogen-fueled engines during the first two of the three year project. With pre IVC engines the fuel is introduced into the combustion chamber prior to closing of the intake valve. This is in contrast to post IVC engines in which fuel is introduced in the cylinder after the intake valve closes. Post IVC engines are to be investigated during the third year according to the project program plan.

This quarterly report is a summary of the work accomplished during the first three months of the project. For completeness it contains information presented in the first two monthly reports.

II. DISCUSSION OF APPROACHES AND ACCOMPLISHMENTS

\section{A FLASHBACK}

As described in the proposal for this project, uncontrolled early ignition or flashback is a problem with pre-intake valve closing (Pre IVC) hydrogen-fueled engines. In fact it is probably the most serious problem to be overcome if hydrogen is to be used in such engines. In order to attain a better understanding of the causes of early ignition the following material was reviewed.

Early ignition and its manifestation in the form of fiashback in the induction system occurs when the fresh hydrogen-air charge ignites prematurely prior to the closing of the intake

* Numbers in square brackets designate references given in Section IV. 
valve. The flame thus generated propogates through the fuel-air delivery system. Some of the causes of early ignition associated with flashback are hot spots in the combustion chamber and residuals.

Previous testing [2] of the Toyota engine described in. Table 1 demonstrated the role played by the spark plug and exhaust valve in forming hot spots and causing early ignition. When gasoline-fueled engine heat range spark plugs were used and the load was increased from idle, flashback commenced. The substitution of lower operating temperature spark plugs was found to alleviate this source of early ignition. As the equivalence ratio was increased further the exhaust valve eventually attained a high enough temperature to cause preignition and flashback. It was found, however, that with the high compression ratio (9.4:1), short duration full load runs could be made without flashback if extreme care was taken to clean the oil from the exhaust valves when properly designed and seated oil rings were used. II. A-1 THERMAL CHARACTERISTICS OF EXHAUST VALVES

It is apparent from the above discussion that proper exhaust valve design will be an important ingredient for Pre IVC engines. The design scheme will depend to a large extent on the thermal characteristics of the valve in combination with the exhaust valve seat and guide. These characteristics and the methods that will be used to ascertain them are described below.

The sodium-filled valve invented by Heron [3] is well known and widely used to lower exhaust valve operating temperatures [4]. Such valves which reduce peak valve temperature by about $200^{\circ} \mathrm{F}\left(110^{\circ} \mathrm{C}\right)$, have been used to extend the useful range. of hydrogen-fueled engines [2]. Testing of water-filled exhaust valves [4], which utilize the enthalpy of vaporization of water to increase heat transfer rates, has shown an additional $300^{\circ} \mathrm{F}$ $\left(166^{\circ} \mathrm{C}\right)$ reduction in peak exhaust valve temperatures. Since the peak temperatures for water-filled valves are found to be near the seat, improved seat design will reduce peak temperatures even further (about $50^{\circ} \mathrm{F}$ ):

original project plans were to characterize sodium and water-filled exhaust valves. Personal communication with Mr. I. Danis of the Eaton Corporation [5] brought to light test 
results using lithium as an internal valve coolant. The results have shown that lithium exhibits very favorable characteristics as an internal valve coolant; they are:

1. Absence of high pressure at operating temperatures.

2. A very high heat transfer coefficient at the lithium cavity wall interface.

3. Scavenging action by lithium keeping the cavity walls clean thereby maintaining 2 ,

4. A slightly better overall heat transfer to the stem than offered by water-filled valves.

As a result of the very encouraging findings regarding the characteristics of lithium-filled exhaust valves and the relative ease of construction, they will be added to the test program. These valves have the potential of bringing the exhaust valve head temperature down to the temperature of the intake valve.

The reduction in exhaust-valve peak temperature with the sodium- water- and lithium-filled exhaust valves (super-conductive valves) is at the expense of a greatly increased temperature level of the valve stem and increased heat rejection requirements by the guide [4].

Valve stem lubrication will be aggravated due to the higher temperature at the valve guide. Lubrication problems; however, are not expected during the project experiments. Redesign of future cylinder heads for hydrogen-fueled engines utilizing superconductive valves could aid in reducing the heat load on the lubricant at the guide. One potential solution would be to lengthen the valve stem and guide and bring the bearing surface higher up on the stem by increasing the valve-guide clearance at the lower portion of the guide. Additionally, modifications would be required to permit more uniform and adequate coolant velocity around some valve guides which currently cannot manage stem heat rejection rates from super-conductive valves [4].

The thermal characteristics of the exhaust valve, seat, stem and guide for solid and super-conductive (sodium- lithiumand water-filled) valves during this project will be determined by monitoring the temperature at select locations in the cylinder head near the valve. A finite element, electrical 
analogue model following the techniques of [6] will be formulated. The measured temperatures will be used to verify the validity of the model and to make appropriate adjustments to the approximate heat transfer coefficients given by Danis [4] which are reproduced in Figure. 1. The model, in conjunction with the measured temperatures, will yield approximate values of peak valve temperature and stem and seat heat rejection requirements for the various valves to be tested.

In order to determine the proper locations near the seat and valve guide for the thermocouples which, will be used for monitoring temperature a Toyota cylinder head was sectioned. Figure 2 is a Xerox of the sectioned head on which the probe locations are shown. The three holes for the guide, temperature probes have been drilled. Chromel-alumel thermocouples sheathed with 0.040 in O.D. stainless steel tubing will be put in the holes and be in contact with the guide. Four holes (one for each cylinder) have been drilled in the other probe location shown in Figure 2 into which the same type of thermocouple probe will be placed in contact with the exhaust valve seat. In addition, another hole was drilled to allow for the installation of another seat probe for the number two cylinder.

The temperature data will also be analyzed to determine if exhaust valve seat temperature, which in turn, is directly related to exhaust valve temperature, can be correlated with individual cylinder air-fuel ratio, detonation, flashback and abnormal combustion.

Sodium filled exhaust valves from the following vehicles were investigated as potential candidates for the present study.

1970 porsche 911s

1968 Porsche 911

1971 Mercedes 250

1969 Mercedes 220

1964 Mercedes 19OSL
1972 Alfa Romeo 2000

1970 Alfa Romeo 1300

1969 Alfa Romeo 1600

1969 Dodge Truck $361 \mathrm{cu}$. in. 1968 Dodge Truck 251 cu. in.

1971 BMW 2000

Where necessary the valve was sectioned to ascertain its relative merit. The Alfa Romeo 1300 co valve was selected as the best candidate. It has a better cavity design near the head of the valve than does its 1600 cc counterpart, thereby making it more suitable. This improved cavity design is shown in Figure 3 where 
it is seen that there is a greater surface area in the cavity at the head of the valve and that there is a smaller distance and thus less thermal resistance between the cavity and the combustion chamber side of the valve. The specifications of the Alfa Romeo 1300 .ce exhaust valve are:

Part Number - 105390330100

Stem Diameter - $0.352^{\prime \prime}$

Head Diameter - $1.34 "$

Length - 4.27"

Seat Angle - $30^{\circ}$

Lock Grove Type - Single Grove

This type valve will be used to construct water- andlithium-filled valves. The construction will involve removing the valve stem tip, emptying the sodium and filling.with water (or lithium) and welding a replacement tip.

II. A-2 RESIDUALS, OIL ENTRA INMENT AND FLASHBACK

The role played by residual gases in causing early ignition was also demonstrated during the testing described in [2]. It is well known that lowering compression ratio increases exhaust gas and thus residual temperature [7]. When the compression ratio was lowered to $7.2: 1$ the short duration tests at full load without flashback as described in II. A could not be performed. This inability to operate without flashback at a lower compression ratio is attributed to the increased residual temperatures. Another observation made during these tests was that the presence of oil in the residual gases enhanced the onset of early ignition. This enhancement was demonstrated by the fact that one of the cylinders commenced to flashback before the others. The piston for this cylinder was modified in such a way as to increase the oil content of the residuals. The piston modification, which involved removal of a portioin of the land above the top compression ring, is shown in Figure $4 a$ where it is seen that there is probably a greater chance for the vortex formed by the piston motion [8] to entrain oil and distribute it into the residual gas for the cylinder with the modified piston. The fact that this cylinder commenced to flashback first lends support to the proposition that oil in the residuals enhances flashback. 
There are two potential ways that the presence of oil in the residuals can enhance flashback: (1) the oil particles serves as nucleation sites; (2) the oil reacts with the oxygen in the combustion gases causing local high temperatures in the residuals. The oil serving as nucleation sites is consistent with other experiments during which city of Miami water ingested with intake air was found to produce severe flashback. When evaporated the water was found to leave a solid residue which was assumed to have formed nucleation sites for early ignition and flashback.

From the above, it is apparent that to avoid flashback, hydrogen engines must be designed to minimize the presence of oil in the combustion chamber. A significant source of extraneous combustion chamber oil is from the cylinder wall. Haskell and Legate [9] have shown that with partially seated rings, the oil found to be present in the exhaust of a motored engine could be eliminated by tapering the cylinder bore 0.01 inches per 6 inches, Figure $4 \mathrm{~b}$. It was postulated [9] that "the oil scraped off the bore by the ring is accommodated by the increasing volume behind the ring." The effects of temperature gradients and mechanical stresses encountered in a fired engine and their effect on the detailed bore configuration and entrainment of cylinder oil into combustion gases, however, is not known. It is also suspected that the piston slap occuring at the end of the exhaust stroke can cause the oil found between the cylinder wall and the circumference of the piston above the top ring to be ejected into the residuals.

Based on the above considerations it has been decided that the effect of oil in the residuals should be investigated. To this end a used Toyota $1600 \mathrm{cc}$ engine with noticeable cylinder wear will be located, disassembled, cleaned and tested. The worn-cylinder engine will exhibit a taper like that shown in Figure 5 and should yield less oil in the exhaust gas as will be determined by Flame Ionization Detector total hydrocarbon measurements. If the engine exhibits lower hydrocarbon emissions, i.e. less oil in the residuals, then a reduction in flashback tendency should be found if the proposition that oil in residual 
gas enhances flashback is a valid one.

With regard to oil in the residuals, it is pertinent to point out that problems previously encountered with the oil control characteristics of the improved three piece, 1971 Toyota engine oil ring sets [2] are supposed to be eliminated by the stock, 1976 oil rings. Thus the stock, 1976 oil control rings will be used.

\section{A-3 TIMED INDUCTION AND FLASHBACK}

On 10 February, 1977, Professor L. Abello from St. Pius College, Bombay, India, visited the University of Miami and informed us of some of the unpublished results he obtained using hydrogen as fuel in a single cylinder engine. In Abello's engine the hydrogen was injected into the intake port. He found that he could get the engine to perform without flashback, that is without early ignition, if he delayed the introduction of the hydrogen until about 40 degrees after the beginning of the intake stroke. The results of his work lend strong support to the proposed solution to hydrogen-fueled engine flashback problems described in the proposal [1] for this project. In the proposal, it was stated that late introduction of hydrogen into the Pre. IVC engine intake charge by a method of timed injection "should eliminate the problem of flashback for a number of reasons: The initial entry of air will reduce the temperature of the residual gases, and there will be an additional time interval during which potential nucleation sites (hot spots) will be cooled by heat transfer to the cooling water and incoming air before hydrogen enters the combustion. chamber".

Calculations have been performed to obtain a first order approximation of the temperature of the gas in the cylinder as a function of crank angle during the intake stroke. Assuming a residual gas temperature of $1000^{\circ} \mathrm{F}$, a compression ratio of 9 to 1 , a Mach index number of 0.25 at 3300 RPM, an adiabatic process, complete mixing, ideal gas behavior and constant specific heats, the cylinder gas temperature was found to drop to $240^{\circ} \mathrm{F}$ at $50^{\circ} \mathrm{F}$ ATC. While only a first approximation, this result, which is consistent with Abello's observations, is very encouraging in 
terms of the second year's work where hydrogen will not enter the cylinder until around $50^{\circ} \mathrm{F}$ ATC.

\section{B CAMSHAFT SELECTION}

Three camshafts will be used during this project: Camshaft A - the stock Toyota camshaft; Camshaft B - tentatively a stock Chrysler camshaft (number 2465852); Camshaft C - a low duration, zero overlap camshaft. Camshaft $A$ will be tested for comparative purposes. Camshaft $B$ will be used for almost all of the testing program. Cams $B$ and $C$ will be made by Crane Cam Inc. They will also measure the lobes of camshaft $A$. The Crane cam Inc. definition of valve opening and closing angle (0.050 inch lift at the lobe) will be used for making specification tables.

Camshaft $\mathrm{C}$ will be used at an operating condition where flashback is experienced with camshaft $B$ in order to test the hypothesis that flashback is not caused by communication of inlet manifold gases with expelled exhaust gases. Since the exhaust lobe of camshaft $C$ will be the same as that of camshaft $B$, the exhaust valve temperature will be very similar during operation with these camshafts. If the engine continues to flashback when it is operated at the same condition when camshaft $C$ is substituted for $B$, then the hypothesis that communication of expelled exhaust gas with intake manifold gas does not cause flashback can be accepted.

Camshaft $B$, the chrysler camshaft, has been tentatively chosen as the one that will be used for the bulk of the testing because it is believed that it will produce torque versus engine speed characteristics similar to the average characteristics found for standard, modern. American passenger cars. The selection of Camshaft $B$ was made not only with consideration of the effects of displacement, intake and exhaust systems flow characteristics, and camshaft lobe profiles on peak-torque RPM, but also on the effects of piston motion versus crank angle. Piston position versus crank angle is a function of the connecting rod length to stroke ratio $(\mathrm{CRL} / \mathrm{S})$ and the piston pin offset. The effert of normal piston pin offset on piston motion versus crank 
angle and peak-torque RPM is, however, small. The relationship between piston position and crank angle plays a significant role in determining the RPM for peak-torque. For example, the peak-torque RPM for a racing engine can be raised by 900 RPM by increasing the $\mathrm{CRL} / \mathrm{S}$ from 1.7 to 1.9. Passenger car $\mathrm{CRL} / \mathrm{S}$ are found to lie between 1.5 and 2.15 , a considerable variation in the light of the racing engine data. The effect of $\mathrm{CRL} / \mathrm{S}$ on peak-torque RPM is further substantiated by observation of the following data for six cylinder engines:

$\begin{array}{llr}\text { ENGINE } & \frac{\text { CRL/S }}{\text { PEAK-TORQU }} \\ 250 \text { CID Chevrolet } & 1.61 & 1600 \\ 232 \text { CID American Motors } & 1.68 & 1600 \\ 240 \text { CID Ford } & 2.14 & 2200\end{array}$

The observed variations in peak-torque RPM cannot be explained by the usual considerations of cam profiles and intake and exhaust systems flow characteristics and displacement alone; the $\mathrm{CRL} / \mathrm{S}$ must also be included in the consideration. The above table of $\mathrm{CRL} / \mathrm{S}$ and peak-torque RPM is not intended to be considered a correlation of $\mathrm{CRL} / \mathrm{S}$ and peak-torque $\mathrm{RPM}$; rather, it is intended only to indicate trends and show that CRL/S had to be considered when the selection of the cam profile for camshaft $B$ was made.

It should also be pointed out that the tentative camshaft $B$ is of the pre-emission control design. It does not have the currently used relatively large overlap. The absence of large overlap is desirable for the first year baseline data because EGR is not wanted except when it is intentionally used.

Final selection of Camshaft $B$ will be made after initial testing during non-hydrogen fueled operation.

II. C TECHNIQUE FOR MEASURING EGR

During the course of the rirst year's work, the effect of EGR on $\mathrm{NO}_{\mathbf{x}}$ production, flashback control, and thermal efficiency will be studied. Since a primary variable is the amount of EGR, expressed as a percentage of the inducted mixture, the accuracy of the measurement of the EGR flow rate is of primary concern. It is difficult to make accurate measurements of EGR flow rate with conventional flow meters. The gas to be measured is exhaust gas which changes in temperature, pressure and composition 
as the engine is varied over the operating range of concern. For example: exhaust gas temperatures at the exhaust port vary from $300^{\circ} \mathrm{F}$ to $1050^{\circ} \mathrm{F}$; the exhaust gas pressure is dependent on EGR passage design, and for a given design, pressure variations will occur at the flow meter with changes in load, air-fuel ratio and EGR flow rate; the constituents of the exhaust gas can vary from approximately $65 \% \mathrm{~N}_{2}$ and $35 \% \mathrm{H}_{2} \mathrm{O}$ at the stoichiometric air-fuel ratio to $78 \% \mathrm{~N}_{2}, 18 \% \mathrm{O}_{2}$ and $4 \% \mathrm{H}_{2} \mathrm{O}$ at the lean limit of combustion. The use of conventional flow meters will also result in substantial changes in the condition of the gas used for EGR: For example, the gas would have to be cooled, which may also result in condensation of water vapor, which in turn will change the No $\mathbf{x}$ reducing characteristics of the EGR.

Because of the above-described problems associated with the use of conventional flow meters to measure EGR flow rate an alternate method of measurement was evolved. During the development of the method it became apparent that present methods of numerically characterizing the amount of hydrogen in a fresh charge do not adequately account for the effect of EGR. Present methods include:

$$
\begin{aligned}
& \% \mathrm{~F} \quad=100 \frac{\text { Volume Hydrogen }}{\text { Total Volume Fresh Charge }} \quad \ldots \ldots \ldots \ldots \ldots \ldots \\
& (\mathrm{F} / \mathrm{A})_{\mathrm{v}}=\quad \frac{\text { Volume Hydrogen }}{\text { Volume Air }} \quad \ldots \ldots \ldots \ldots \ldots \ldots \ldots \\
& (F / A)_{m}=\frac{\text { Mass Hydrogen }}{\text { Mass Air }} \\
& \% \mathrm{~F}=\frac{\% \mathrm{~F}}{(\% \mathrm{~F})_{\text {stoichiometric }}} \\
& \Phi_{v}=\frac{(F / A)_{v}}{(F / A)_{v}, \text { stoichiometric }}
\end{aligned}
$$

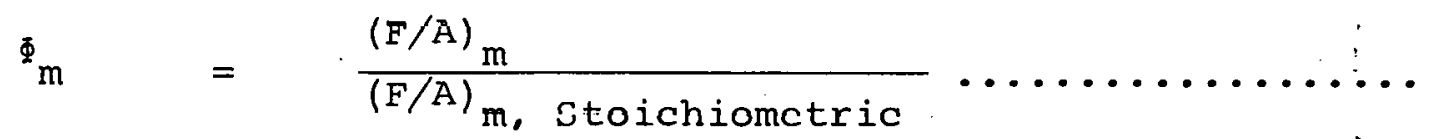

Instead of the above-defined fuel-air ratio parameters, the following parameter, termed the hydrogen-oxygen equivalence ratio, will be used during the present investigation: 


$$
\begin{aligned}
& =\frac{\text { Volume Hydrogen/Volume oxygen }}{\text { (Volume Hydrogen/Volume oxygen) }} \text { Stoichiometric } \\
& =0.5 \frac{(\text { Volume Hydrogen })}{\text { (Volume oxygen) }} \quad \ldots \ldots \ldots \ldots \ldots \ldots \ldots \ldots \ldots
\end{aligned}
$$

The advantage of $\Psi$ is that it equals unity, independent of the EGR flow rate, when there is just the right amount of oxygen present in the charge to oxidize all of the hydrogen.

values of the above fresh charge parameters are given in Table 2 for various mixture compositions and EGR rates. The table shows that the parameter $Y$ is the only one that takes into account the fact that at leaner than stoichiometric conditions the EGR gas is composed in part of oxygen which results in a leaning-out of the mixture.

The alternate method of determining the EGR rate involves the measurement of oxygen concentration in the EGR (exhaust) gas $\left[\mathrm{O}_{2}\right]_{\text {EGR }}$ and in the fresh charge composed of hydrogen, fuel and EGR gas $\left[\mathrm{O}_{2}\right]_{\mathrm{mix}}$. as well as the measurement of air volume flow rate $\dot{V}_{a}$ and hydrogen volume flow rate $\dot{V}_{h}$. The following equation was derived and can be used to calculate the \% EGR from these measurements

$$
\% \text { EGR }=100 \frac{\mathrm{F}_{\mathrm{a}}\left[\mathrm{O}_{2}\right]_{\mathrm{a}}-\mathrm{F}_{\mathrm{h}}\left[\mathrm{O}_{2}\right]_{\mathrm{m}}-\mathrm{F}_{\mathrm{a}}\left[\mathrm{O}_{2}\right]_{\mathrm{m}}}{\mathrm{F}_{\mathrm{a}}\left[\mathrm{O}_{2}\right]_{\mathrm{a}}-\mathrm{F}_{\mathrm{h}}\left[\mathrm{O}_{2}\right]_{\mathrm{EGR}}-\mathrm{F}_{\mathrm{a}}\left[\mathrm{O}_{2}\right]_{\mathrm{EGR}}}
$$

In Equation (9) the $F_{i}$ 's are nondimensional volume flows defined by

$$
F_{i}=\frac{\dot{V}_{i}}{V_{m}}
$$

where $\dot{V}_{m}$ is the fresh charge volume flow rate (air plus hydrogen plus EGR gas). The fresh charge volume flow rate is given in terms of measured parameters by the following equation:

$$
\dot{\mathrm{v}}_{\mathrm{m}}=\frac{\left[\mathrm{O}_{2}\right]_{\mathrm{F}, \mathrm{R}}\left(\dot{\mathrm{V}}_{\mathrm{a}}+\dot{\mathrm{V}}_{\mathrm{h}}\right)-\dot{\mathrm{v}}_{\mathrm{a}}\left[\mathrm{O}_{2}\right]_{\mathrm{a}}}{\left[\mathrm{O}_{2}\right]_{\text {EGR }}-\left[\mathrm{O}_{2}\right]_{\mathrm{m}}} \text {. }
$$

In deriving Equations (3) and (1), it was assumed that the air, hydrogen and EGR gas are ideal gases at equal temperature and pressure before mixing. The equation will be derived relaxing the assumptions of equal temperature and pressure and be included in a future report. 
An analysis was performed to determine the maximum experimental uncertainties expected using the above-described $\left[\mathrm{O}_{2}\right]$ method of \% EGR determination. In the analysis the following uncertainties were assumed:

$\begin{array}{ll}\dot{\mathrm{v}}_{\mathrm{a}} & : \pm 0.0075 \text { reading } \\ \dot{\mathrm{v}}_{\mathrm{h}} & : \pm 0.0050 \text { reading } \\ {\left[\mathrm{O}_{2}\right]_{\mathrm{mix}}} & : \pm 0.0005 \text { oxygen fraction } \\ {\left[\mathrm{O}_{2}\right]_{\text {EGR }}} & : \pm 0.0005 \text { oxygen fraction } .\end{array}$

Room air was assumed to be composed of $21 \%$ oxygen by volume. Table 3 contains the result of the analysis. For each of the methods $\left(\left[\mathrm{O}_{2}\right]\right.$ method or $\dot{\mathrm{V}}_{\mathrm{EGR}}$ method) two numbers are given for each combination of $Y$ and \% EGR. These numbers give the upper and lower bounds on the measured \% EGR. For example at $Y=0.85$ with $25 \%$ EGR the value of $\%$ EGR as determined by the $\left[\mathrm{O}_{2}\right]$ method will lie between $24.2 \%$ and $25.8 \%$ while that determined by the $\dot{\mathrm{V}}_{\text {EGR }}$ method will lie between $23.3 \%$ and $26.7 \%$. In estimating the uncertainty for the $\dot{V}_{E G R}$ method the uncertainty in the measurement of EGR flow rate was assumed to be $6 \%$ or the reading. The uncertainty $g$ iven is labeled maximum because the calculations were performed assuming all of the measured parameters to be at their extreme values to yield either the maximum or minimum value of $\%$ EGR. The results in the table shows that the proposed method of determining \% EGR is a good one. 
A behavior of hydrogen alluded to in reports and at conferences as being an important characteristic is its high rate of diffusion in air. For example, it is tacitly assumed that because of its high diffusion rate rapid mixing should take place in intake manifolds of carburetted engines alleviating cylinder-to-cylinder distribution problems. An order of magnitude analysis of the diffusion equation in the absence of pressure gradients, temperature gradients and force fields (Fick's law), as presented below, however, shows that the diffusion rate of hydrogen in air is of such a magnitude as to make it unimportant during residence times encountered by the working fluid in automotive engines.

The one dimensional form of Fick's law in terms of diffusion velocity, $\mathrm{C}_{\mathrm{H}}-\mathrm{C}_{\mathrm{A}}$, for a binary mixture is [10]:

$$
\mathrm{C}_{\mathrm{H}}-\mathrm{C}_{\mathrm{H}}=-\frac{\mathrm{D}_{\mathrm{HA}}}{\mathrm{u}_{\mathrm{H}} \mathrm{u}_{\mathrm{A}}} \frac{\mathrm{du} \mathrm{u}_{\mathrm{H}}}{\mathrm{dx}},
$$

where $D_{H A}$ is the coefficient of diffusion; $u_{H}$ is the concentration of hydrogen; $u_{A}$ is the concentration of air which is considered to be a single component gas and $d u_{H} / d u_{A}$ is the concentration gradient. Consider a near stoichiometric mixture of hydrogen and air: $u_{H}=0.3 ; u_{A}=0.7 ; d u_{H}$ is of the order $u_{H}$ and $d x$ is of the order of the dimensions in an intake manifold: $1 \mathrm{ft.,}$ and $\mathrm{D}_{\mathrm{HA}}=0.00458 \mathrm{ft}^{2} / \mathrm{sec}$. For these values Fick's law yields diffusion velocities having the order of magnitude of $0.001 \mathrm{ft} / \mathrm{sec}$. Thus, in an operating engine where gas velocities are of the order of $100 \mathrm{ft} / \mathrm{sec}$ molecular diffusion of hydrogen is of no real importance in intake manifolds.

An order of magnitude analysis similar to the above was performed to estimate the order of the diffusion velocity in the presence of a pressure gradient caused by induced swirl of the fresh charge and in the presence of temperature gradients resulting from the introduction of fresh charge into the hot cylinder. This analysis also showed negligibly small diffusion velocities. From these order of magnitude considerations, it 
is apparent that induced swirl and/or temperature gradients will not cause homogeneous hydrogen-air mixtures to stratify. It does show that if the intake process involves the induction of fresh air with induced swirl and if hydrogen is introduced in such a manner as to result in a stratified charge, turbulence and not diffusion will be the governing mechanism in causing the stratified charge to become homogeneous.

An order of magnitude analysis of the diffusion velocity in the presence of force field, as would be found in the vicinity of the spark plug during ignition, has not been carried. Such an analysis will be performed and discussed in another report.

One work area given in the proposal for this project [1] is the formulation of a mathematical model which would give a first-order estimate of the hydrogen concentration distribution in the fresh charge. In the light of the above-described order of magnitude analysis it is evident that concentration distributions predicted by such a model will not be attained from a homogeneous mixture because of the relatively low diffusion velocities. For completeness, however, the analysis is presented below. original plans were to include only the effect of swirling. motion of the fresh charge on the distribution. Subsequent analysis has shown, however, that, at low swirl rates corresponding to low engine speeds, a nonuniform temperature similar in magnitude to the nonuniformity found during normal engine operation is much more effective in producing concentration gradients than the swirl. Because of this dominant influence of temperature nonuniformity on concentration distribution it has been incorporated into the analysis.

\section{D-1 ANALYSIS}

The kinetic theory of nonuniform gases [10] ỹields the following general equation of diffusion for a binary mixture (Assumption $1 ;$ the assumptions made are listed at the end of the analysis): 
$\bar{C}_{1}-\bar{C}_{2}=\frac{n^{2}}{n_{1} n_{2}} D_{12}\left[\Delta u+\frac{u_{2}\left(m_{2}-m_{1}\right)}{p} \Delta \ln p-\frac{p_{1} p_{2}}{p p}\left(F_{1}-F_{2}\right)+K_{T} \frac{I}{T} \Delta T\right]$

where:

$\overline{\mathrm{C}}_{1}-\overline{\mathrm{C}}_{2}=$ velocity of diffusion vector;

$n_{s}=$ number density of molecule $s$;

$\mathrm{n}=$ number density of molecules in mixture;

$$
=\mathrm{n}_{1}+\mathrm{n}_{2}
$$

$\mathrm{D}_{12}=$ coefficient of mutual diffusion of the binary mixture;

$\mathrm{u}=\mathrm{n}_{1} /\left(\mathrm{n}_{1}+\mathrm{n}_{2}\right)$

$m_{s}=$ mass of molecule $s$;

$\mathrm{p}$ =pressure;

$p_{s}=$ partial density of constituent $s$;

$p=p_{1}+p_{2} ;$

$F_{s}=$ external force vector acting on molecule $s$ divided by mass of molecule $s$; i.e. external force vector on molecule $\mathrm{s}$ equals $\mathrm{m}_{\mathrm{s}} \mathrm{F}_{\mathrm{s}}$;

$\mathrm{K}_{\mathrm{T}}=$ thermal diffusion ratio;

$\mathrm{T}=$ temperature;

$\underline{\Delta}=$ gradient operator .

Except for the region in the vicinity of the spark plug gap during ignition, the external force vector, $\underline{F}_{S^{\prime}}$ is zero. The electrustalic force field produced diring ignition has no significant effect on the swirl; therefore,

$$
\underline{F}_{1}-\underline{F}_{2}=0 \text {. }
$$

The effect of the electrostatic force field during ignition on the fresh charge in the spark plug gap will be the subject of another report.

The gradient operator in cylindrical coordinates is:

$$
\underline{\Delta}_{\underline{u}} \underline{\underline{u}} \frac{\bar{\partial}}{\partial r}+\underline{u}_{\theta} \frac{\mathfrak{l}}{r} \frac{\partial}{\partial \theta}+\underline{u}_{z} \frac{\partial}{\partial z} \text {; }
$$

where the unit vector $\underline{u}_{r}$ is in the radial direction, $\underline{u}_{\theta}$ in the tangential direction and $\underline{u}_{z}$ along the axis of the piston-cylinder. For axisymmetry (Assumption 2) and no variation with $z$ (Assumption 3) Equation (17) becomes 


$$
\Delta=\underline{u}_{r} \frac{\mathrm{d}}{\mathrm{dr}}
$$

For steady state (Assumption 4)

$$
\overline{\mathrm{C}}_{1}-\overline{\mathrm{C}}_{2}=0
$$

Equations (12), (16), (18) and (19) yield

$$
0=\frac{d u}{d r}+\frac{u_{2}\left(m_{2}-m_{1}\right)}{p} \frac{d l n p}{d r}+k_{T} \frac{1}{T} \frac{d T}{d r} .
$$

To determine the pressure field consider the equation of motion for a Newtonian or Stokes fluid (Assumption 5) with constant viscosity (Assumption 6) [11]

$$
p\left(\frac{\partial \underline{V}}{\partial \underline{E}}+(\underline{v} \cdot \underline{\Delta}) \underline{V}\right)=p \underline{G}-\underline{p}+\frac{\mu}{3} \underline{\Delta}(\underline{\Delta} \cdot \underline{V})+\mu \Delta^{2} \underline{V} ;
$$

Where:

$$
\begin{aligned}
\underline{v} & =\text { bulk velocity vector } \\
& =\underline{u}_{r} v_{r}+\underline{u}_{\theta} v_{\theta}+\underline{u}_{z} v_{z} \\
G & =\text { external body force vector } \\
& =0 \quad \ldots \ldots \ldots \ldots \ldots \ldots \ldots \ldots \ldots \ldots \\
\mu & =\text { viscosity. }
\end{aligned}
$$

In this first-order approximation analysis the swirling gas mixture is considered to be rotating with a velocity distribution

$$
\begin{aligned}
& v_{r}=0 \\
& v_{\theta}=r \omega \\
& v_{z}=0 .
\end{aligned}
$$

where $\omega$ is the angular velocity of the swirling gas mixture (in this approximation the nonuniform gas rotates as a solid body). Equations (18), (21), (22), (23), (24) and (25) and (Assumption 4) yields

$$
\frac{d p}{d r}=-p \omega^{2} r
$$

Using Equation (26), the following equation for density

$$
p=n_{1} m_{1}+n_{2} m_{2}
$$

the equation of state for a perfect gas mixture (Assumption 1) 


$$
p=k T\left(n_{1}+n_{2}\right),
$$

(where the Boltzmann constant [12]

$$
\left.\mathrm{k}=1.3804 \times 10^{-16} \mathrm{erg} /{ }^{\circ} \mathrm{K}\right) \text {. }
$$

and the fact that

$$
\frac{n_{2}}{n_{1}+n_{2}}=1-u
$$

Equation (20) becomes

$$
0=\frac{d u}{d r}+\frac{\left(m_{2}-m_{1}\right) \omega}{k T} u(1-u) r+K_{T} \frac{1}{T} \frac{d T}{d r} .
$$

In order to arrive at a first-order estimate of the influence of nonuniform charge temperature on the hydrogen concentration distribution, the temperature is assumed to vary according to the following equation:

$$
\mathrm{T}=\mathrm{T}_{0}+\Delta \mathrm{T}\left(\mathrm{x} / \mathrm{r}_{\mathrm{w}}\right)^{2}
$$

where $\mathrm{T}_{\mathrm{O}}$ is the temperature at center of the cylinder;

$$
\Delta \mathrm{T}=\mathrm{T}_{\mathrm{w}}-\mathrm{T}_{0} ;
$$

and $T_{w}$ is the temperature at the outer radius of the cylinder, $r_{w}$. Equation (32) is consistent with the assumption of axisymmetry and is of the same functional form as the solution to heat transfer in a. long solid circular cylinder with uniformly distributed heat sinks and constant thermal conductivity [13]. The Equation (32) temperature distribution is not the exact one for the binary perfect gas mixture. It is useful for the present analysis however, because it reduces the non-steady state heat transfer process in the fresh charge to a steady state process by the inclusion of heat sinks and should give the desired first-order effect of nonuniform temperature on the concentration field at steady. state.

Substitution of Equation (32) into Equation (31) and expressing the thermal diffusion ratio, $K_{T}$, in terms of the thermal diffusion factor, $\alpha,[10]$

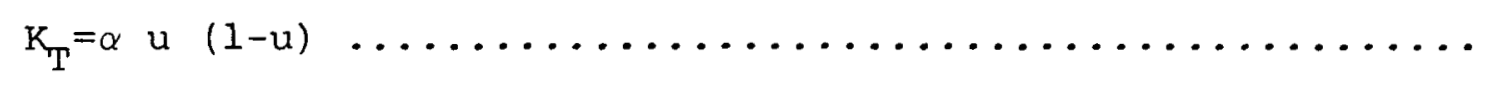

yields

$$
-\frac{d u}{u(1-u)}=\Gamma \frac{x d x}{T_{0}+\Delta T x^{2}}
$$


where

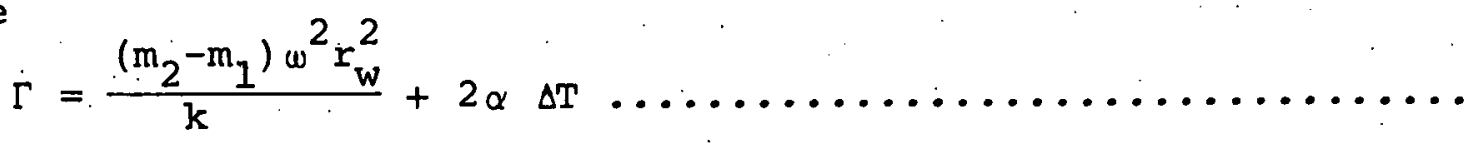

and

$$
\mathrm{x}=\mathrm{r} / \mathrm{r}_{\mathrm{w}}
$$

The relation between $u$ and $r$ is found by integration of Equation (26) from the center line of the cylinder where the hydrogen concentration is $u_{0}$ to $r$. This integration yields:

$$
\ln \left(\frac{1-u}{u}: \frac{u_{0}}{1-u_{0}}\right)=\frac{\Gamma}{2 \Delta T} \ln \left[1+\frac{\Delta T}{T_{0}}\left(\frac{r}{r_{w}}\right)^{2}\right]
$$

To determine the effects of swirl alone, temperature nonuniformity alone, and the combined effects of swirl and nonuniform temperature on the hydrogen concentration distribution Equation (38) was solved for $u$ as a function of $r$ for the following three cases:

CASE 1 - Swirl with Uniform Temperature ( $\dot{\omega} \neq 0, \Delta \mathrm{T}=0$ )

$$
u=1+\frac{1-u_{0}}{u_{0}} \exp \left[\frac{\Gamma_{\omega}}{T_{0}} \frac{1}{2}\left(\frac{r}{r_{w}}\right)^{2}\right]^{-1}
$$

where

$$
\Gamma_{\omega}=\frac{\left(m_{2}-m_{1}\right) \omega^{2} r_{w}^{2}}{k}
$$

CASE 2 - Zero Swirl with Nonuniform Temperature ( $\omega=0, \Delta T \neq 0$ )

$u=\left\{1+\frac{1-u_{0}}{u_{o}}\left[1+\frac{\Delta T}{T_{o}}\left(\frac{r}{r_{w}}\right)^{2}\right]^{\alpha}\right\}^{-1}$

CASE 3 - Swirl with. Nonuniform Temperature ( $w \neq 0, \Delta \mathrm{T} \neq 0$ )

$u=\left\{1+\frac{1-u_{0}}{u_{0}}\left[1+\frac{\Delta T}{T_{0}}\left(\frac{r}{r_{w}}\right)^{2}\right]^{2 \Delta T / \Gamma}\right\}^{-1}$

II. D-2 ASSUMPTIONS AND APPROXIMATIONS - SUMMARY

The swirling fresh charge is considered to have a cylindrical shape and the following assumption and approximations are incorporated in the model.

1. The charge is a binary perfect gas mixture

2. Axisymmetry

3. No variation with the axial dimension $z$

4. Steady state

5. The charge is a Newtonian or Stokes Fluid 
6. Constant viscosity (this assumption is not necessary in the light of assumption 7).

7. The velocity distribution is the same as that of a solid rotating at an angular velocity $\omega$.

8. The nonsteady state heat transfer process has been reduced to quasi-steady state by considering the gas to be composed of heat sinks and the temperature distribution for steady state heat transfer in a long cylinder of constant thermal conductivity is used for the temperature profile.

II. D-3 NUMERICAL EXAMPLES

Numerical examples of the three cases are given below. In arriving at these examples, it was necessary to assume values for the angular velocity, w, of the swirling charge. The angular velocity is related to the engine speed, $N$, by the swirl ratio [14, 15]

$$
\Omega=\frac{\omega}{2 \pi N}
$$

In the numerical examples the swirl ratio is assumed to be independent of engine speed. This is a reasonable approximation for present purposes. The value of $\Omega=10$ used in the examples is attainable in a reasonably well-designed engine.

It was also necessary to assume a value for $\Delta T$ in the examples. The value chosen is $200^{\circ} \mathrm{F}$. This is a reasonable, if not conservative, estimate of $\Delta \mathrm{T}$ : Calculations assuming a fuel charge temperature of $80^{\circ} \mathrm{F}$, a compression ratio of 10 , and a pressure of about 150 psi after compression (Toyota specification) yield average charge temperatures on the order of $100^{\circ} \mathrm{F}$, the exact value depending on the temperature and amount of residuals. Thus as a first-order approximation $\mathrm{T}_{0} \approx 100^{\circ} \mathrm{F}$. Since combustion chamber wall temperatures are on the order of $400^{\circ} \mathrm{F}, \mathrm{T}_{\mathrm{w}} \approx 400^{\circ} \mathrm{F}$. These estimates of $\mathrm{T}_{\mathrm{O}}$ and $\mathrm{T}_{\mathrm{w}}$ yield, according to Equation (33), $\Delta \mathrm{T}=400-100=300^{\circ} \mathrm{F}$. Thus the value of $\Delta \mathrm{T}=200^{\circ} \mathrm{F}$ used in the calculations in a reasonabie, conservative estimate. The remainder of the values of the parameters used in the numerical examples are: 


$$
\begin{aligned}
\mathrm{m}_{1} & =\text { mass of hydrogen molecule } \\
& =0.332 \times 10^{-23} \mathrm{gm} \\
\mathrm{m}_{2} & =\text { mass of "air" molecule } \\
& =4.81 \times 10^{-23} \mathrm{gm} \\
\alpha & =0.28 \\
\mathrm{~T} & =300^{\circ} \mathrm{K}\left(540^{\circ} \mathrm{R}\right)
\end{aligned}
$$

The value of $r_{w}=1.675$ in. is the radius of the Toyota $2 \mathrm{TC}$ engine to be used in this project.

In Table 5 the percent hydrogen in the swirling charge at steady state (100u) is given: at five values of radius $(0.0$, $0.4,0.7,1.0,1.5,1.675 \mathrm{in.}) ;$ for three engine speeds (800 RPM or idle; $1800 \mathrm{RPM}$ and $3000 \mathrm{RPM}) ;$ and for four values of $U_{0}$ (4.1\% or lean 1imit; 10\%; 20\%; and 30\%, which is near the stoichiometric value of 29.6). The Table 1 entries have been plotted in Figures (5). (6) and (7). The results of calculations performed for an engine speed of 6000 RPM omitted from the table is included in Figure (8) for a near stoichiometric mixture. This latter result corresponds to near peak power operation.

\section{D-4 DISCUSSION}

As discussed in section II. D, these results are presented for completeness. The resulting concentration distributions apply to steady state conditions which, as a result of the relatively short residence time of the mixture in a hydrogen engine are not obtainable if an initially homogeneous mixture is ingested by the engine. Non-homogeneous, stratified charges, however, can be realized by proper design. 
Since the confidence level of measured brake thermal efficiency and fuel-air equivalence ratio are critically dependent upon the accuracy of fuel flow and air flow rate measurements a survey was made of the available flow rate measuring devices. With the help of Dr. David W. Baker of the National Bureau of Standards Fluid Mechanics Department, Table 5 was compiled to aid in the selection of the fuel flow rate measuring method to be used throughout the project.

Among the criteria for the fuel flow meter selection are: high precision, high accuracy, availability of hydrogen cali-. bration facilities, ease of maintenance, long lived repeatability and accuracy, low fuel line pressure requirements and reasonable cost. It is also felt desirable to have more than one meter to bridge the entire range of fuel flow rate (140 to 1 ). With multiple meters the ranges can be overlapped. This overlapping will afford the opportunity to conduct pretest calibration checks in the overlap regions.

\section{E-1 FUEL FLOW METER}

Based on the above considerations, high precision rotameters with a precision of $\pm 0.2 \%$ of reading and an accuracy of $0.5 \%$ of reading have been selected as the means of measuring the fuel flow rate.

Calibration for standard application, high accuracy flow meters is conducted by using air as a flow medium and then correcting using the appropriate theoretical correction factors for the fluid to be metered in practice. This procedure results in accuracies of $\pm 1 \%$ for high precision meters. Special applications requiring greater accuracy are handled by calibrating with the fluid to be used in practice or a fluid that closely approximates the physical flow properties of the fluid to be used in practice (Cox Instruments calibrates with helium for hydrogen approximation). Calibration using hydrogen as a working fluid is not standard practice. The increased accuracy obtained by hydrogen calibration is not a common request and the potential safety hazard of venting hydrogen during or after calibration is 
not a task looked upon favorably.

Since high precision flow meters offer a high degree of accuracy through calibration with hydrogen, a search was made to find a facility to perform this calibration. As a result of this search the Colorado Experimental Engineering Station, Inc., Boulder, Colorado, has been contracted to calibrate the hydrogen fuel flow meters. They will calibrate the meters to an accuracy of $\pm 0.5 \%$ of reading; the calibration will be conducted at 12 points for each meter with 6 of the points being repeated. With regard to fuel flow meter selection, readability is a major contributor to total accuracy when high accuracy is desired in a rotameter; it varies with the length, dynamic range, and type of tube taper. For example, cox gives a readability of $1 \%$ for their logarithmic tube 120 model which has a large dynamic range (13:1) and $0.5 \%$ for their logarithmic tube 129 model which has a small dynamic range (5:1).

The fuel flow meter chosen is the Cox Model 129-287-Range. It is composed of 3 logarithmic tubes that will maintain readability at about ${ }^{\prime \prime} \pm 0.5 \%$ of reading.

II. E-2 AIR FLOW METER

Air flow rate measurement will be made using a laminar flow element. with an accuracy of $\pm 0.75 \%$ of reading coupled with a high precision inclined monometer having an accuracy of \pm 0.25 of readings. The instruments selected are:

Meriam 50 MC2-2F Laminar Flow Element Meriam 40H35, 50" Scale Manometer

II. F SOLID STATE LOGIC IGNITION INTERRUPTER

To determine the effects of ignition failure on hydrogenfueled engine performance during some of the tests the ignition will be interrupted every Yth time a spark plug should be activated. This interruption will be effected by the solid state logic ignition interrupter, SSLII, circuit shown in Figure 6. This circuit differs from the one given in the proposal. At the input, two monostable multivibrators have been added to prevent any errors from distributor point bounse. At the output, a transistor has been added to serve 
as a switch to carry the relatively high current needed to trigger the capacitive discharge, $C D$, ignition. The Figure 6 circuit has been constructed on patchboard and preliminary testing shows that it performs as required.

II. G ENGINE BREAK IN

Since breaking in of the engine on hydrogen was considered to be too costly, original plans called for breaking in the engine using LPG. Subsequent investigation has revealed that the break in time using LPG is too long. It has thus been decided to break in the engine on gasoline for 20 hours and then to disassemble it and to clean it before running on hydrogen. Discussions regarding break in of a hydrogen engine brought up the possibility of using special break in oils if and when hydrogen engines become used on a wide-scale basis.

II. $\mathrm{H}$ ENG INE OIL (LUBRICANT)

Valvoline gas engine oil $\mathrm{AD}-1$, part number 413, SAE 30 weight has been chosen as the engine oil lubricant for the present study mainly because of its low ash content. This is the same oil recommended for natural gas-fueled engines.

II. I CARBURETION SYSTEMS

An Impco gaseous carburetion system consisting of a Ca125M mixer W/A3-60+AFl-5, a JB-2 converter, and a VFF30-2 vacuum fuel lock will be used for almost all of the carburetted engine configurations. For comparison purposes, cylinder-to-cylinder distribution data will be taken at a selected data point using a Beam gaseous carburetion system.

\section{J OXIDES OF NITROGEN MEASUREMENTS}

In order to prevent the potential loss of $\mathrm{NO}_{2}$ in the water which is condensed from nonheated samples, it has been decided to usc a heated sample for nxides of nitrogen analysis. It was decided to use the vacuum reaction chamber type chemiluminescent ${ }^{N O} x$ analyzer manufactured by Thermo Electron (Model $10 \mathrm{~A}$ rack mounted). To avoid the $\mathrm{H}_{2}$ interference in the $\mathrm{NO}_{2}$ to NO converter during rich stoichiometry [17] an air bleed will be in- 
stalled upstream of the converter. The sample will be kept heated above the dew point up to the heated capillaries. II. $\mathrm{K}$ OTHER CONSIDERATIONS

To measure engine torque and absorb the power output, a Go-Power Systems Model D-312 dynamometer absorbtion unit will be used.

Data will be permanently recorded during testing by two methods. The first involves the use of strip chart recorders for engine torque and speed, as well as the exhaust emissions. The second will involve taking a photograph of the remainder of the measurements on a single frame of film. The remainder of the measurements include up to 12 thermocouple EMF's rotameters, monometers, pressure gauges, etc.

\section{L EQUIPMENT RECEIVED OR CONSTRUCTED}

Complete engine from the Toyota assembly line in Japan Two cylinder heads

Short Block

Valves, springs, locks, retainers, guides

Impco Carburetor

Beam Carburetor

Chrysler 170 C.I.D. engine camshaft

Toyota 1600 camshaft \#13511-25010

Cylinder Head preparation for thermocouple probes

Engine stand

Heated exhaust sample line and power supply

Go-Power Model D-311 Dynamometer

Assorted exhaust valves

Toyota valve seats (uncut), Alfa Romeo valve guides

Meriam 40HE35 precision manometer

Flexhaust air flow hose

Thermocouple probes, thermocouple wire, connectors

12 cylinders Industrial Grade Hydrogen

Hydrogen manifolds, regulators, filters

Used Toyota 1600 cc engine

II. M EQUIPMENT ON ORDER

Thermo Electron Model IOA rack mounted chemiluminescent $\mathrm{NO}_{\mathbf{x}}$ analyzer with air bleed upstream of converter and heâted capillaries.

Cox Model 129-287 - Range 2 fuel flow meter and calibration by colorado Engineering Station, Inc.

Meriam Laminar Flow Element 50MC2-2F

Beckman oxygen analyzer pick-up head, cable and sensor

Sunstrand - combustion pressure transducer, adapter and cable Crane Cams Inc. - camshaft type B

Bosch fuel injectors 


\section{CONSULTATION $\left(\mathrm{H}_{2}\right.$ ENGINE TECHNOLOGY EFFICIENCY - CONF IGURATION}

On 23 February, the day was spent in consultation with Prof. Robert F. McAlevy of Stevens Institute of Technology and Dr. C. R. Krishna, Brookhaven National Laboratory. The purpose of the consultation was to discuss at their request the use of hydrogen-fueled engines for automotive application. We submitted to them our best estimates of hydrogen-fueled engine brake thermal efficiency versus brake mean effective pressure characteristics for two cases. The first case was for a hydrogen engine that could be built to power a vehicle the size of a Vega using today's hydrogen-engine technology; the second for an engine employing near term future hydrogen engine technology for the same vehicle. The engine design based on today's technology was of the unthrottled type. To control flashback and $\mathrm{NO}_{\mathbf{x}}$ emissions the fuel-air equivalence ratio was limited to 0.5 . To regain the performance loss imposed by this limitation, the engine displacement was doubled. The second-case hydrogen engine was of the same displacement as a gasoline. engine using methods to control $\mathrm{NO}_{\mathbf{x}}$ emissions and flashback to be developed during this Hydrogen Engine Performance project. The information we supplied to McAlevy and Krishna will be used in a Lawrence Livermoore Laboratory report in which comparisons will be made of various automotive propulsion systems; for example, hydrogen systems vis-a-vis battery systems. 
[1] Response to U.S. ERDA RFP No. E(04-3)-1212 Hydrogen Engine Performance Analysis Project by University of Miami and Hawthorne Research and Testing, Inc., April, 1976.

[2] Swain, M. R., Masters Thesis, University of Miami, "Hydrogen-Air Internal Combustion Engine", 1973.

[3] U.S. Patent 1670965, May 22, 1928 [4].

[4] Danis, L. J., "Engine Valve Cooling" SAE Paper Number 730055, Jan. 1973.

[5] Danis, L. J.., Personal Communication, Circa, Jan. 1977.

[6] Hires, S. D. and Pochmara, G. I., "An Analytical Study of Exhaust Gas Heat Loss in a Piston Engine Exhaust Port", SAE Paper Number 760767.

[7] Taylor, C. F., and Taylor, E. S., The Internal-Combustion Engine, International Textbook Company, Scranton, Pennsylvania, 1966.

[8] Tabaczynski, R. J., Hoult, D. P., and Keck, J . C :, "High Reynolds Number Flow in a Moving Corner". J. Fluid Mech., Vol. 42, 1970.

[9] Haske11, W. W., and Legate, C. E.. "Exhaust Hydrocarbon Emissions from Gasoline Engines - Surface Phenomena", S.A.E. Paper Number 720255 .

[10] Chapman, S. and cowling, T. G. The Mathematical Theory of Nonuniform Gases, Second Edition, Cambridge University Press, 1964.

[11] Prandtl, L. and Tietjens, O. G.. Fundamentals of Hydroand Aeromechanics, McGraw=Hill Book, Co., Inc, , 1934.

[12] Present, R. D., Kinetic Theory of Gases, McGraw-Hill Book Co. Inc., 1958.

[13] Kreith, F., Principles of Heat Transfer, International Textbook Co.., Second Edition, 1968.

[14] Huebner, K. H., and McDonald, A. T.. "Experimental Determination of Airflow Patterns in Piston Engines with Induction Swirl", SAE Paper Number 720026. 
IV. REFERENCES (cont.)

[15] Willis, D. A., Meyer, W. E. and Birnie, C., "Mapping of Air Flow Patterns in Engines With Induction Swirl", SAE Paper Number 660093.

[16] Woolley, R. I. and Henriksen, D. L., "Water Induction in Hydrogen - Powered IC Engines", International Journal of Hydrogen Energy, Volume 1, No. 4; 1977.

[17] Siewert, R. M.," Hydrogen Interference in Chemiluminescent NO Analysis", Combustion and Flame, Vol. 25(2), October, 1975. 
1 Toyota 27-C 4 cylinder Hemispherical Combustion Chamber Engine

$20 \%$ EGR - 25\% EGR

3 Illustrate, the Maximum Uncertainty Expected in \% EGR Determination by oxygen Concentration Measuring Method, $\left[\mathrm{O}_{2}\right]$, and Direct EGR Flow Rate Measuring Method $\mathrm{V}_{\mathrm{EGR}}$.

4. Percent Hydrogen, $100 \mathrm{u}$, as a Function of Radius $r$, for the Three cases [See Text: Case (1) $\Delta \mathrm{T}=0 ; \omega \neq 0 ;$ Case (2) $\omega=0 ; \Delta \mathrm{T} \neq 0$; Case (3) $\Delta \mathrm{T} \neq 0, \omega \neq 0]$ for various Values of Cylinder Centerline Hydrogen Concentration, $\mathrm{u}_{\mathrm{O}}$, and Engine speed, RPM. (For all cases the Swirl Ratio, $\Omega$, Equals 10).

5 Fuel Flow Meter Characteristcs 


\section{$\underline{T A B I E I}$}

Toyota 27-C 4 Cyljnder Hemispherical combustion Chamber: Engine

Displacement:

$1588 \mathrm{cc}$ or 96.9 cubic inches.

Bore diameter: $80 \mathrm{~mm}$ or 3.346 inches.

Stroke length: $70 \mathrm{~mm}$ or 2.756 inches.

Compression ratio: 9.4 to 1 reduced to 7.2 to 1 .

Compression pressure at $250 \mathrm{R}$. P.M.: $12.0 \mathrm{Kg} / \mathrm{cm}^{2}$ or $170.6 \mathrm{psi}$. Maximum horsepower (SAE) : 102 horsepower at 6000 R.P.M. Maximum torque (SAE): 101 foot-pounds at 3800 R.P.M.

\section{Stock Camshaft}

Intake valve opens: $\quad 16^{\circ}$ R.T.D.C. (a) 0.006 inch lohe lift Intake valve closes: $\quad 54^{\circ}$ A.B.D.C. (a) 0.006 inch lobe lift Exhaust valve opens: $58^{\circ}$ B.B.D.C. @ 0.006 inch lobe life Exhaust valve closes: $12^{\circ}$ A.T.D.C. @. 0.006 inch lobe lift

Lift: Intake at cam: . .252 inch

Exhaust at cam: .252 inch

\section{Lower Residual Camshaft}

Intake valve opens: $\quad 9^{\circ}$ B.T.D.C. @ 0.006 inch lobe lift Intake valve closes: $50^{\circ}$ A.B.D.C. @ 0.006 inch lobe lift Exhaust valve opens: $51^{\overline{0}}$ B.B.D.C. @ 0.006 inch lobe lift Exhaust valve closes: $8^{\circ}$ A.T.D.C. @ 0.006 inch lobe lift

Lift: Intake at cam: .220 inch Exhaust at cam: .220 inch

Valve clearance, hot, intake: $0.20 \mathrm{~mm}$ or 0.007 inch valve clearance, hot, exhaust: $0.33 \mathrm{~mm}$ or 0.013 inch

Ignition timing: $\quad 5^{\circ}$ B.T.D.C. at 650 R.P.M. Firing order: 1342

Engine o1l capacily: 3.7 liters or 3.9 U.S. quarts 
TABLE 2

0 \% EGR

\begin{tabular}{|llllllll|}
\hline MIXTURE & $Y$ & $\Phi_{\mathrm{m}}$ & $\Phi_{\mathrm{v}}$ & $\Phi_{\%}$ & $(\mathrm{~F} / \mathrm{A})_{\mathrm{m}}$ & $(\mathrm{F} / \mathrm{A}) \mathrm{v}$ \\
\hline Stoichiometric & 1.0 & 1.0 & 1.0 & 1.0 & 0.025 & 0.420 & 29.6 \\
Peak NO & 0.8 & 0.8 & 0.8 & 0.85 & 0.0234 & 0.334 & 25.2 \\
Easy Operation & 0.4 & 0.4 & 0.4 & 0.50 & 0.0121 & 0.174 & 14.8 \\
Lean Linit & 0.1 & 0.1 & 0.1 & 0.14 & 0.0029 & 0.042 & 4.0 \\
\hline
\end{tabular}

$25 \%$ EGR

\begin{tabular}{|lllll|}
\hline MIXTURE * & $\mathrm{Y}$ & $\Phi_{\mathrm{m}}$ & $\Phi_{\mathrm{v}}$ & $\Phi_{\%}$ \\
\hline 1.0 & 1.0 & 1.0 & 0.75 \\
& 0.75 & 0.8 & 0.8 & 0.64 \\
& 0.35 & 0.4 & 0.4 & 0.38 \\
& 0.076 & 0.1 & 0.1 & 0.10 \\
\hline
\end{tabular}

* The $25 \%$ EGR mixture is composed of $75 \%$ of the mixture given in the 0\% EGR table plus $25 \%$ exhaust gas which in all but the first entry (stoichiometric mixture) contains oxygen. 


\section{TABISE 3}

Illustrate, the Maximum Uncertainty Expected in \% EGR Determination by oxygen Concentration Measuring Method, $\left[\mathrm{O}_{2}\right]$, and Direct EGR Flow. Rate Measuring Method $\dot{\mathrm{V}}$ EGR.

\begin{tabular}{|c|c|c|c|c|c|c|}
\hline$Y$ & \multicolumn{2}{|c|}{1.00} & \multicolumn{2}{|c|}{0.85} & \multicolumn{2}{|c|}{0.60} \\
\hline$\%$ EGR & {$\left[\mathrm{O}_{2}\right]$} & $\dot{\mathrm{V}}_{\mathrm{EGR}}$ & {$\left[\mathrm{O}_{2}\right]$} & $\dot{\mathrm{V}}_{\mathrm{EGR}}$ & {$\left[\mathrm{O}_{2}\right]$} & $\dot{\mathrm{V}}_{\text {EGR }}$ \\
\hline 5 & $\begin{array}{l}4.3 \\
5.7\end{array}$ & $\begin{array}{l}4.7 \\
5.3\end{array}$ & $\begin{array}{l}4.2 \\
5.8\end{array}$ & $\begin{array}{l}4.6 \\
5.4\end{array}$ & $\begin{array}{l}4.0 \\
6.0\end{array}$ & $\begin{array}{l}4.6 \\
5.4\end{array}$ \\
\hline 15 & $\begin{array}{l}14.3 \\
157\end{array}$ & $\begin{array}{l}14.0 \\
16.0\end{array}$ & $\begin{array}{l}14.2 \\
15.8\end{array}$ & $\begin{array}{l}14.0 \\
16.0\end{array}$ & $\begin{array}{l}14.1 \\
15.9\end{array}$ & $\begin{array}{l}13.5 \\
15.5\end{array}$ \\
\hline 25 & $\begin{array}{l}24.3 \\
25.7\end{array}$ & $\begin{array}{l}23.4 \\
26.7\end{array}$ & $\begin{array}{l}24.2 \\
25.8\end{array}$ & $\begin{array}{l}23.3 \\
26.7\end{array}$ & $\begin{array}{l}24.1 \\
25.9\end{array}$ & $\begin{array}{l}22.5 \\
27.5\end{array}$ \\
\hline 35 & $\begin{array}{l}34.3 \\
35.7\end{array}$ & $\begin{array}{l}32.7 \\
37.3\end{array}$ & $\begin{array}{l}34.3 \\
35.7\end{array}$ & $\begin{array}{l}32.6 \\
37.4\end{array}$ & $\begin{array}{l}34.1 \\
35.9\end{array}$ & $\begin{array}{l}31.5 \\
38.5\end{array}$ \\
\hline 45 & $\begin{array}{l}44.3 \\
45.7\end{array}$ & $\begin{array}{l}42.0 \\
48.0\end{array}$ & $\begin{array}{l}44.3 \\
45.7\end{array}$ & $\begin{array}{l}41.9 \\
48.1\end{array}$ & $\begin{array}{l}44.1 \\
45.9\end{array}$ & $\begin{array}{l}40.5 \\
49.5\end{array}$ \\
\hline
\end{tabular}


Table 4 - Percent Hydrogen, $100 \mathrm{u}$, as a Function of Radius $r$, for the Three Cases [See Text: Case (1) $\Delta \mathrm{T}=0 ; \omega \neq 0$; Case (2) $\omega=0, \Delta T \neq 0$; Case (3) $\Delta T \neq 0, \omega \neq 0]$ for various Values of Cylinder Centerline Hydrogen Concentration, $\mathrm{u}_{\mathrm{o}}$, and Engine Speed, RPM. (For all cases the swirl fatio, $\Omega$, equals 10).

\begin{tabular}{|c|c|c|c|c|c|c|c|c|}
\hline CASE & RPM & $0.0^{R}$ & $\begin{array}{l}D \text { I U S } \\
0.4\end{array}$ & 0.7 & $1.0^{\mathrm{I}}$ & $\begin{array}{lll}N & C \\
1.5 & E & S\end{array}$ & 1.675 & $u_{w}-u_{0}$ \\
\hline $\begin{array}{l}1 \\
2 \\
3\end{array}$ & $\begin{array}{l}800 \\
800 \\
800\end{array}$ & $\begin{array}{l}4.10 \\
4.10 \\
4.10\end{array}$ & $\begin{array}{l}4.10 \\
4.06 \\
4.06\end{array}$ & $\begin{array}{l}4.09 \\
3.98 \\
3.98\end{array}$ & $\begin{array}{l}4.09 \\
3.87 \\
3.86\end{array}$ & $\begin{array}{l}4.08 \\
3.65 \\
3.64\end{array}$ & $\begin{array}{l}4.07 \\
3.57 \\
3.55\end{array}$ & $\begin{array}{l}0.03 \\
0.53 \\
0.55\end{array}$ \\
\hline $\begin{array}{l}1 \\
2 \\
3\end{array}$ & $\begin{array}{l}1800 \\
1800 \\
1800\end{array}$ & $\begin{array}{l}4.10 \\
4.10 \\
4.10\end{array}$ & $\begin{array}{l}4.09 \\
4.06 \\
4.05\end{array}$ & $\begin{array}{l}4.07 \\
3.98 \\
3.96\end{array}$ & $\begin{array}{l}4.05 \\
3.87 \\
3.84\end{array}$ & $\begin{array}{l}4.01 \\
3.65 \\
3.59\end{array}$ & $\begin{array}{l}3.98 \\
3.57 \\
3.49\end{array}$ & $\begin{array}{l}0.12 \\
0.53 \\
0.61\end{array}$ \\
\hline $\begin{array}{l}1 \\
2 \\
3\end{array}$ & $\begin{array}{l}3300 \\
3300 \\
3300\end{array}$ & $\begin{array}{l}4.10 \\
4.10 \\
4.10\end{array}$ & $\begin{array}{l}4.07 \\
4.06 \\
4.03\end{array}$ & $\begin{array}{l}4.02 \\
3.98 \\
3.91\end{array}$ & $\begin{array}{l}3.94 \\
3.87 \\
3.73\end{array}$ & $\begin{array}{l}3.74 \\
3.65 \\
3.40\end{array}$ & $\begin{array}{l}3.66 \\
3.57 \\
3.28\end{array}$ & $\begin{array}{l}0.44 \\
0.53 \\
0.82\end{array}$ \\
\hline $\begin{array}{l}1 \\
2 \\
3\end{array}$ & $\begin{array}{l}800 \\
800 \\
800\end{array}$ & $\begin{array}{l}10.00 \\
10.00 \\
10.00\end{array}$ & $\begin{array}{c}10.00 \\
9.91 \\
9.90\end{array}$ & $\begin{array}{l}9.99 \\
9.72 \\
9.72\end{array}$ & $\begin{array}{l}9.98 \\
9.47 \\
9.46\end{array}$ & $\begin{array}{l}9.95 \\
8.97 \\
8.93\end{array}$ & $\begin{array}{l}9.94 \\
8.78 \\
8.74\end{array}$ & $\begin{array}{l}0.06 \\
1.22 \\
1.26\end{array}$ \\
\hline $\begin{array}{l}1 \\
2 \\
3\end{array}$ & $\begin{array}{l}1800 \\
1800 \\
1800\end{array}$ & $\begin{array}{l}10.00 \\
10.00 \\
10.00\end{array}$ & $\begin{array}{l}9.98 \\
9.91 \\
9.98\end{array}$ & $\begin{array}{l}9.95 \\
9.72 \\
9.68\end{array}$ & $\begin{array}{l}9.90 \\
9.47 \\
9.36\end{array}$ & $\begin{array}{l}9.78 \\
8.97 \\
8.81\end{array}$ & $\begin{array}{l}9.73 \\
8.78 \\
8.60\end{array}$ & $\begin{array}{l}0.27 \\
1.22 \\
1.40\end{array}$ \\
\hline $\begin{array}{l}1 \\
2 \\
3\end{array}$ & $\begin{array}{l}3300 \\
3300 \\
3300\end{array}$ & $\begin{array}{l}10.00 \\
10.00 \\
10.00\end{array}$ & $\begin{array}{l}9.94 \\
9.91 \\
9.85\end{array}$ & $\begin{array}{l}9.82 \\
9.72 \\
9.56\end{array}$ & $\begin{array}{l}9.63 \\
9.47 \\
9.16\end{array}$ & $\begin{array}{l}9.18 \\
8.97 \\
8.37\end{array}$ & $\begin{array}{l}8.99 \\
8.78 \\
8.09\end{array}$ & $\begin{array}{l}1.01 \\
1.22 \\
1.91\end{array}$ \\
\hline $\begin{array}{l}1 \\
2 \\
3\end{array}$ & $\begin{array}{l}800 \\
800 \\
800\end{array}$ & $\begin{array}{l}20.00 \\
20.00 \\
20.00\end{array}$ & $\begin{array}{l}19.99 \\
19.83 \\
19.83\end{array}$ & $\begin{array}{l}19.98 \\
19.51 \\
19.49\end{array}$ & $\begin{array}{l}19.96 \\
19.06 \\
19.03\end{array}$ & $\begin{array}{l}19.91 \\
18.15 \\
18.08\end{array}$ & $\begin{array}{l}19.89 \\
17.81 \\
17.73\end{array}$ & $\begin{array}{l}0.11 \\
2.19 \\
2.27\end{array}$ \\
\hline $\begin{array}{l}1 \\
2 \\
3\end{array}$ & $\begin{array}{l}1800 \\
1800 \\
1800\end{array}$ & $\begin{array}{l}20.00 \\
20.00 \\
20.00\end{array}$ & $\begin{array}{l}19.97 \\
19.83 \\
19.81\end{array}$ & $\begin{array}{l}19.92 \\
19.51 \\
19.43\end{array}$ & $\begin{array}{l}19.83 \\
19.06 \\
18.91\end{array}$ & $\begin{array}{l}19.61 \\
18.15 \\
17.86\end{array}$ & $\begin{array}{l}19.52 \\
17.81 \\
17.47\end{array}$ & $\begin{array}{l}0.48 \\
2.19 \\
2.53\end{array}$ \\
\hline $\begin{array}{l}1 \\
2 \\
3\end{array}$ & $\begin{array}{l}3300 \\
3300 \\
3300\end{array}$ & $\begin{array}{l}20.00 \\
20.00 \\
20.00\end{array}$ & $\begin{array}{l}19.89 \\
19.83 \\
19.73\end{array}$ & $\begin{array}{l}19.67 \\
19.51 \\
19.21\end{array}$ & $\begin{array}{l}19.34 \\
19.06 \\
18.49\end{array}$ & $\begin{array}{l}18.54 \\
18.15 \\
17.06\end{array}$ & $\begin{array}{l}18.19 \\
17.81 \\
16.53\end{array}$ & $\begin{array}{l}1.81 \\
2.19 \\
3.47\end{array}$ \\
\hline $\begin{array}{l}1 \\
2 \\
3\end{array}$ & $\begin{array}{l}800 \\
800 \\
800\end{array}$ & $\begin{array}{l}30.00 \\
30.00 \\
30.00\end{array}$ & $\begin{array}{l}29.99 \\
29.78 \\
29.77\end{array}$ & $\begin{array}{l}29.97 \\
29.36 \\
29.33\end{array}$ & $\begin{array}{l}29.95 \\
28.76 \\
28.72\end{array}$ & $\begin{array}{l}29.88 \\
27.54 \\
27.45\end{array}$ & $\begin{array}{l}29.85 \\
27.08 \\
26.98\end{array}$ & $\begin{array}{l}0.15 \\
2.92 \\
3.02\end{array}$ \\
\hline $\begin{array}{l}1 \\
2 \\
3\end{array}$ & $\begin{array}{l}1800 \\
1800 \\
1800\end{array}$ & $\begin{array}{l}3 \cap .0 n \\
30.00 \\
30.00\end{array}$ & $\begin{array}{l}29.96 \\
29.78 \\
29.74\end{array}$ & $\begin{array}{l}29.89 \\
29.36 \\
29.25\end{array}$ & $\begin{array}{l}29.78 \\
28.76 \\
28.56\end{array}$ & $\begin{array}{l}29.50 \\
27.54 \\
27.16\end{array}$ & $\begin{array}{l}29.37 \\
27.08 \\
26.63\end{array}$ & $\begin{array}{l}0.63 \\
2.92 \\
3.37\end{array}$ \\
\hline $\begin{array}{l}1 \\
2 \\
3\end{array}$ & $\begin{array}{l}3300 \\
3300 \\
3300\end{array}$ & $\begin{array}{l}30.00 \\
30.00 \\
30.00\end{array}$ & $\begin{array}{l}29.86 \\
29.78 \\
29.64\end{array}$ & $\begin{array}{l}29.57 \\
29.36 \\
28.96\end{array}$ & $\begin{array}{l}29.13 \\
28.76 \\
28.00\end{array}$ & $\begin{array}{l}28.06 \\
27.54 \\
26.07\end{array}$ & $\begin{array}{l}27.60 \\
27.08 \\
25.35\end{array}$ & $\begin{array}{l}2.40 \\
2.92 \\
4.65\end{array}$ \\
\hline
\end{tabular}


TAB L E 5

FUEL FLOW METER CHARACTERISTICS

\begin{tabular}{|c|c|}
\hline MEASURING METHOD & ACCURACY* \\
\hline $\begin{array}{l}\text { Anemometer Mass Flow } \\
\text { Transcucer (Temp. }\end{array}$ & $\begin{array}{l} \pm 2 \% R^{+} \text {plus } \\
\pm 0.4 \% R \text { per } 10^{\circ} \mathrm{F}\end{array}$ \\
\hline Compensated) & $\begin{array}{l} \pm 0.5 \% \mathrm{FS}^{++} \text {plus } \\
\pm 0.4 \% \text { FS per } \\
100_{\mathrm{F}}\end{array}$ \\
\hline
\end{tabular}

\section{CALIBI:ATION}

GAS

A:r

High P.ccuracy

Rotameters

$\pm 1 \% R$

Air

Air

Air

Critical Flow

Nozzle

Turbine Meter $\pm 1 \% \mathrm{R}$

$\pm 1 \% \mathrm{R}$

$\pm 1 \% \mathrm{R}$

$$
\pm 0.2 \% R
$$

$\pm 0.2 \% R$
PRECISION * *

RANGE

100 to 1 $\pm 1 \% R$

$\pm 1 \% R$

(1)

REMARKS

$\pm 0.5 \%$ FS accuracy yields greater than $\pm 2 \%$ accuracy at lower end of meter range. Consecutive sized meters do not overlap in the $\pm 2 \%$ accuracy range.

13 to 1

3 to 1

$\triangle \mathrm{P}$ measurement with precision inclined monometer accuracy \pm 0.25 to $\pm 0.5 \%$.

10 to 1

Requires relatively high upstream pressure which is undesirable. Expensive

Additional electronics accuracy

of up to $\pm 0.1 \%$. Expensive.

bearing maintenance a consideration.

- Accuracy is defined as the closeness to the true flow rate.

* Precision is defined as the repeatability of the measurement for a fixed flow rate.

$+\quad \% R=$ percentage of reading.

$++\% F S=$ percentage of full scale. 


\section{LIST OF FIGURES}

FIGURES TITLE

$\underline{\text { PAGE }}$

1 Approximate Local Heat Transfer Coeefficients at Significant Operating Yalve Interfaces and Masses in $\mathrm{B}$ l'U
$\left(\mathrm{w} / \mathrm{cm}^{2} \mathrm{O}_{\mathrm{C}}\right)$ - Taken From $[4]$.

2 Illustrates Locations of Temperature Probes in the cylinder Head.

3 Illustrates Improved cavity Design of the Alfo Romeo $1300 \mathrm{cc}$ Exhaust Valve.

4a. Illustrates the Modification to the Piston used to Increase oil in the Residuals.

$4 \mathrm{~b}$ Illustrates the taper found by Haskell and Legate [9] to Reduce oil in the Exhaust of a Motored Engine.

5 Diffusion Model Equilibrium Hydrogen Concentration Distribution, $\mathrm{u}_{0}=10 \%$.

6 Diffusion Model Equilibrium Hydrogen Concentration Distribution, $u_{0}=20 \%$.

7 Diffusion Model Equilibrium Hydrogen Concentration Distribution, $u_{0}=30 \%$.

8 Diffusion Model Equilibrium Hydrogen Concentration Distribution at High Speed, High Load. 42 


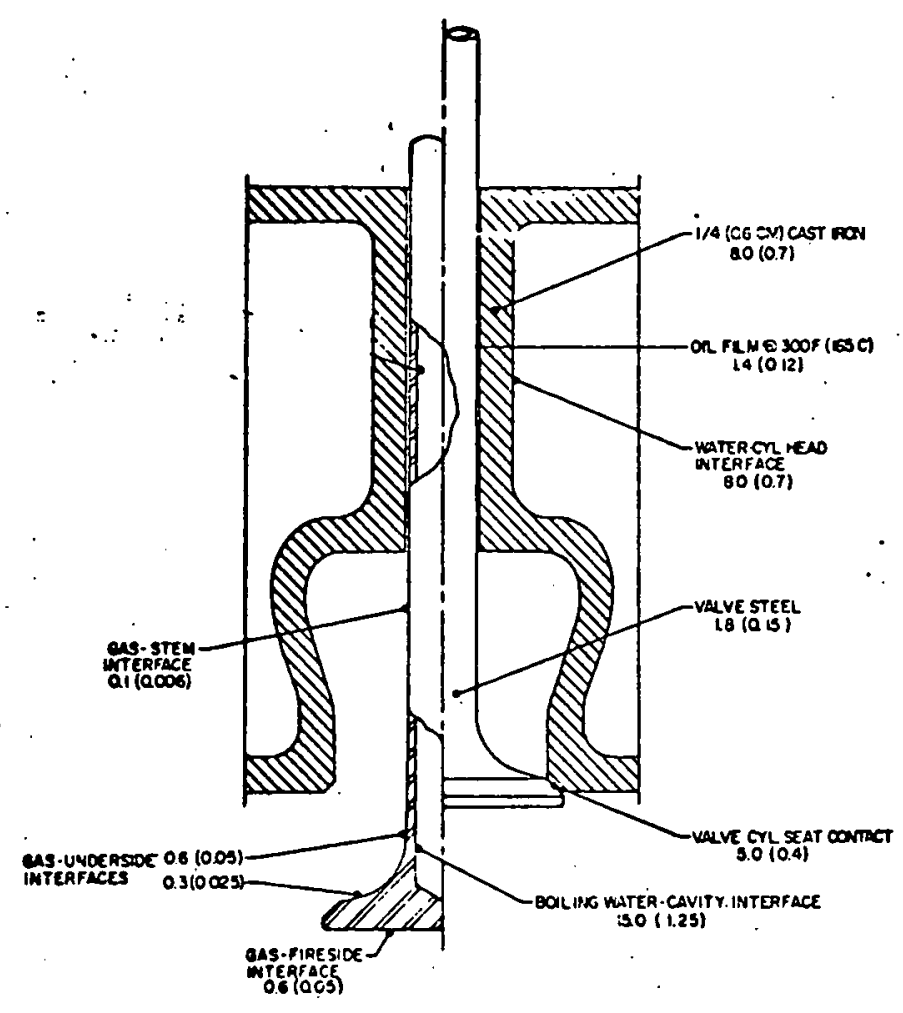

Figure 1 - Approximate Local Heat Transfer Coefficients at Significant Operating Valve Interfaces and Masses in $\mathrm{BTU} / \mathrm{HR}$ in. $2 \mathrm{O}_{\mathrm{F}}\left(\mathrm{w} / \mathrm{cm}^{2} \mathrm{O}_{\mathrm{C}}\right)$ - Taken From [4]. 


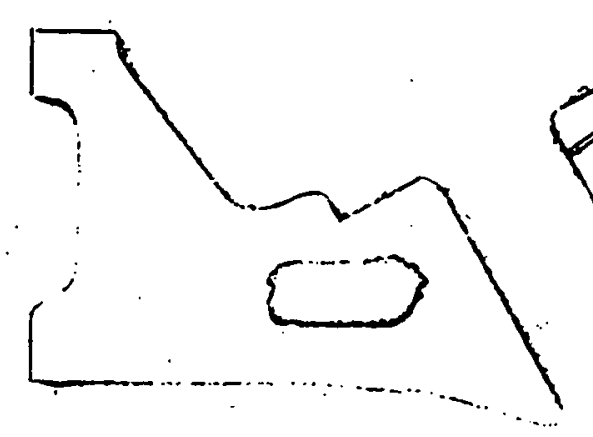

Exhaust Port

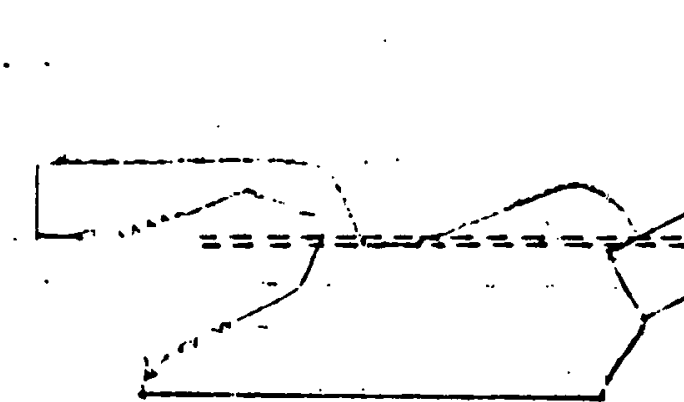

Exhaust Valve seat Temperature Probe Holes

\section{Temperature Probe Holes}
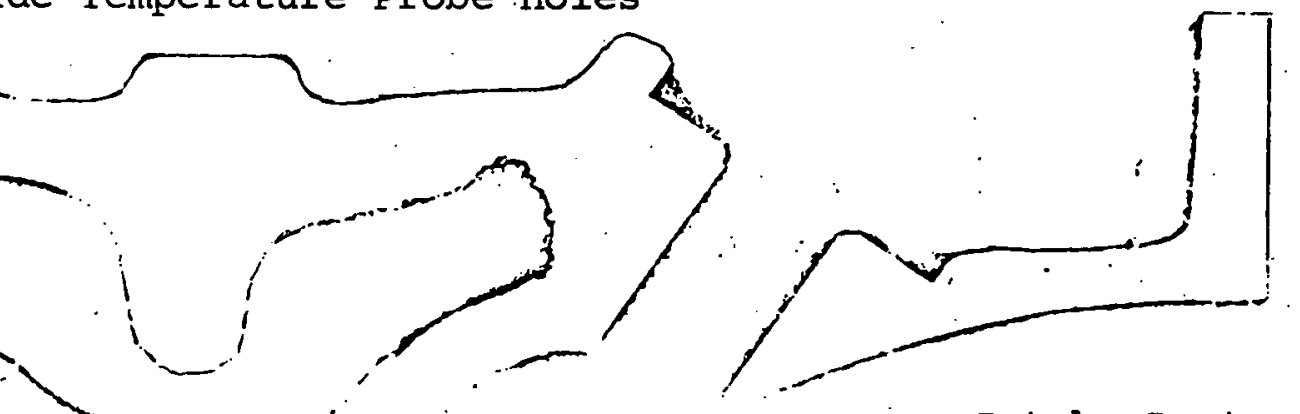

Intake Port

Figure 2 - Illustrates Locations of Temperature Probes in the Cylinder Head. 


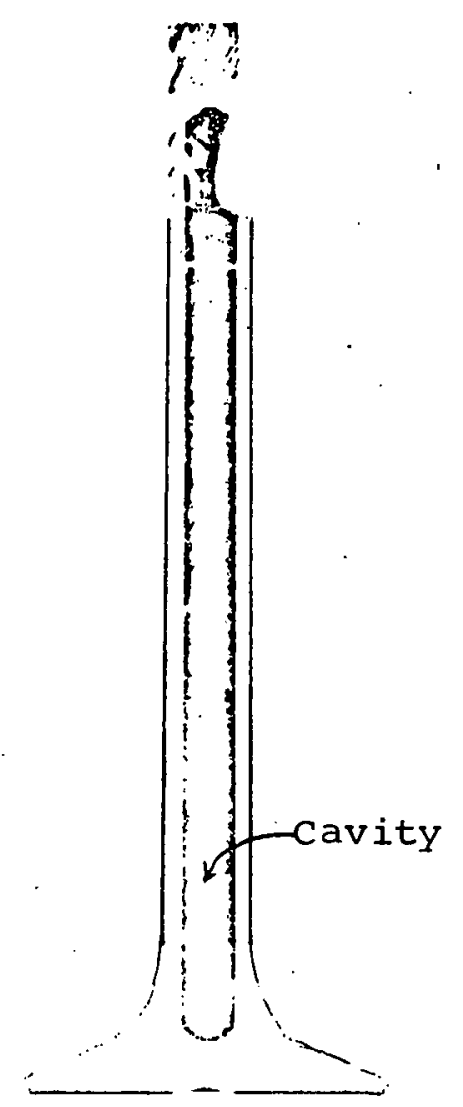

Alpha Romeo $1600 \mathrm{cc}$

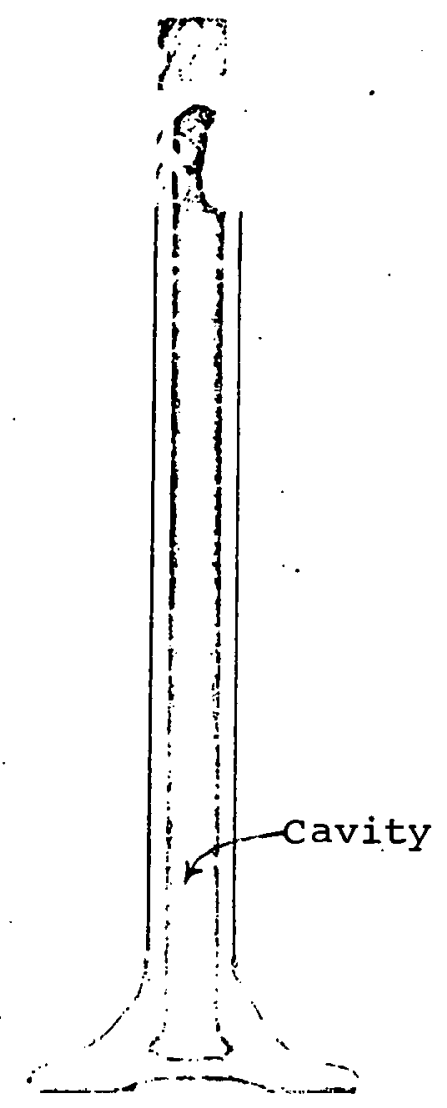

Alpha Romeo $1300 \mathrm{cc}$

Figure 3 - Illustrates Improved Cavity Design of the Alfo Romeo 1300 cc Exhaust Valve. 


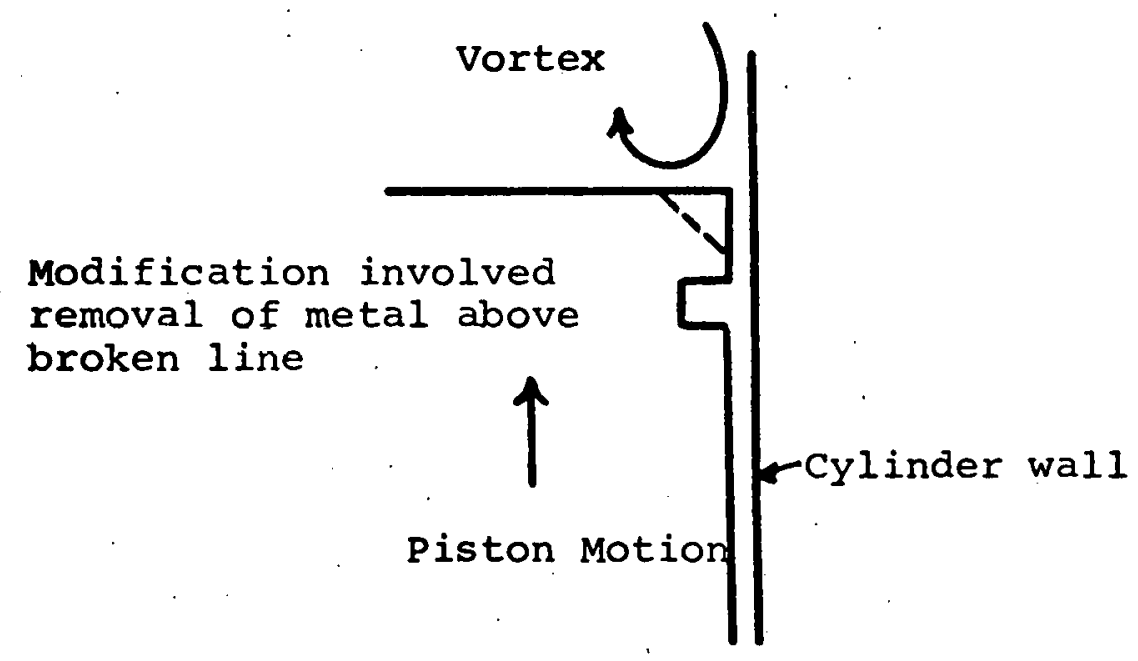

Figure 4a - Illustrates the modification to the piston used to increase oil in the residuals.

Increasing volume that accommodates oil

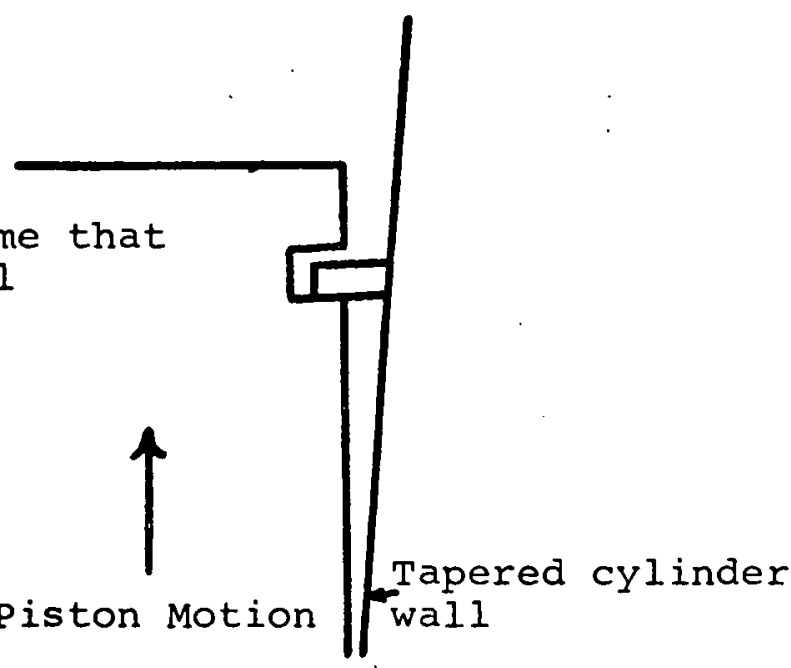

Figure $4 \mathrm{~b}$ - Illustrates the taper found by Haskell and Legate [9] to reduce oil in the exhaust of a motored engine. 


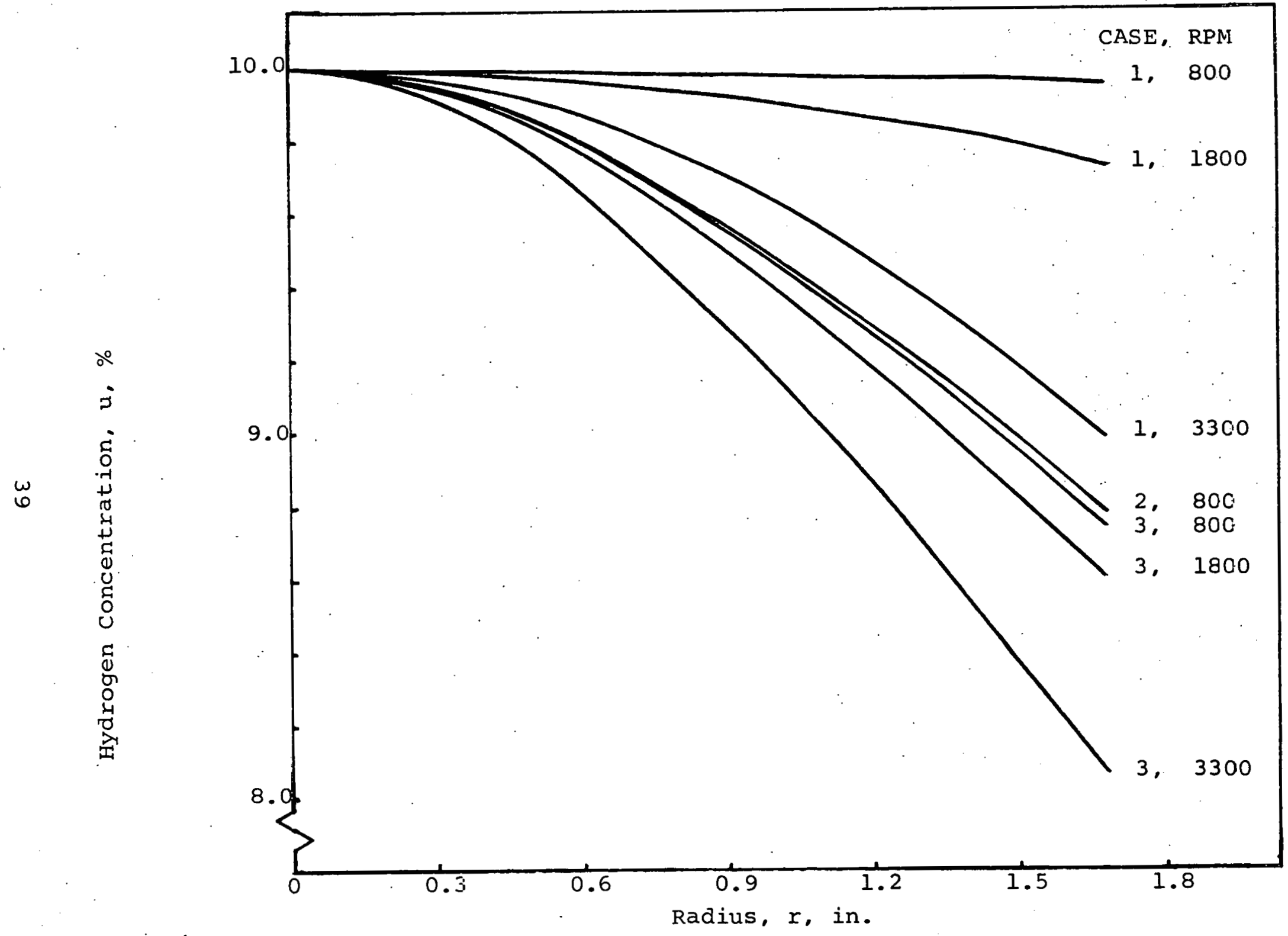

Figure 5 - Diffusion Model Equilibrium Hydrogen Concentration Distribution, $u_{0}=10 \%$. 


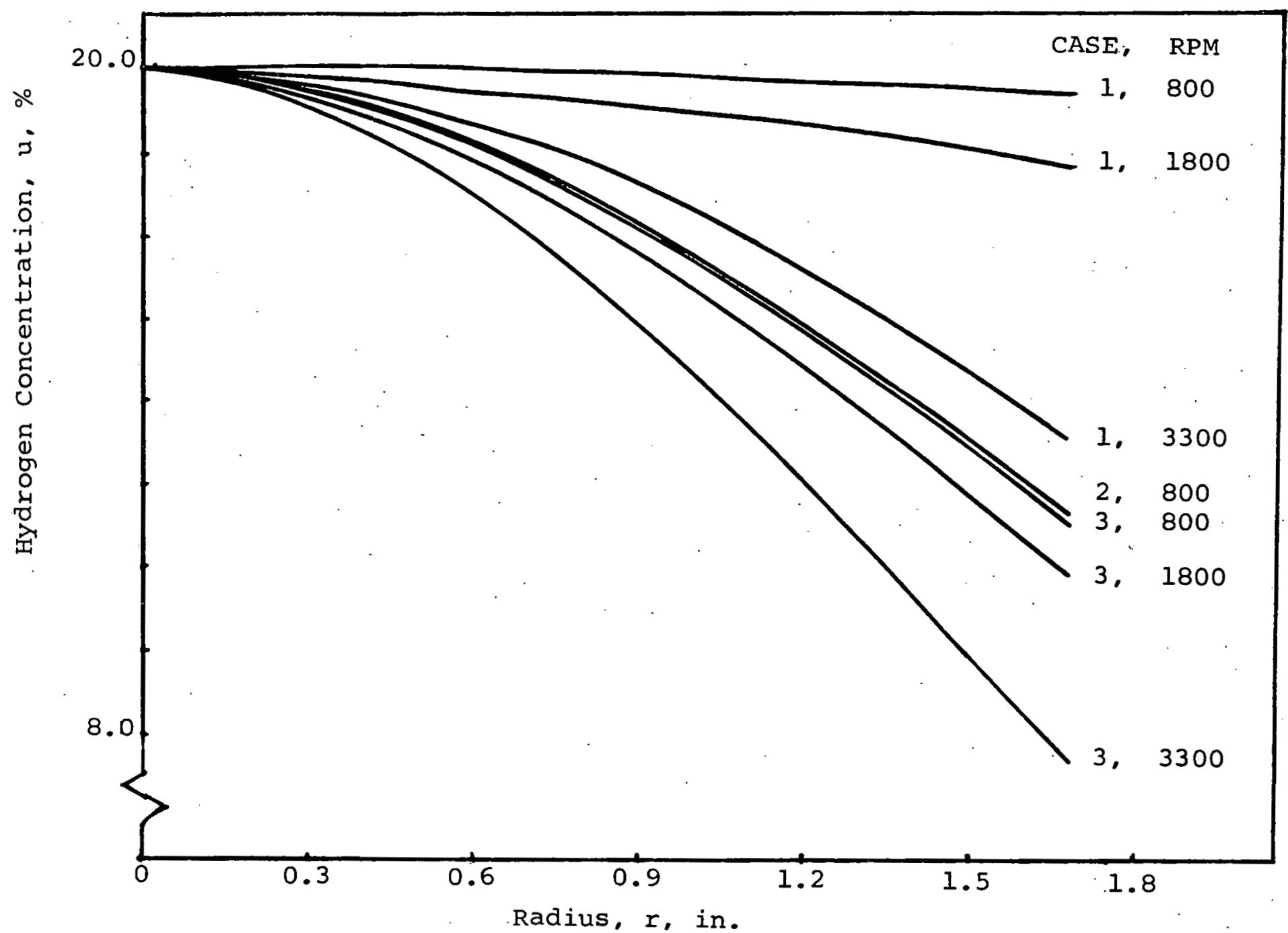

Figure 6 - Diffusion Model Equilibrium Hydrogen Concentration Distribution, $u_{c}=20 \%$. 


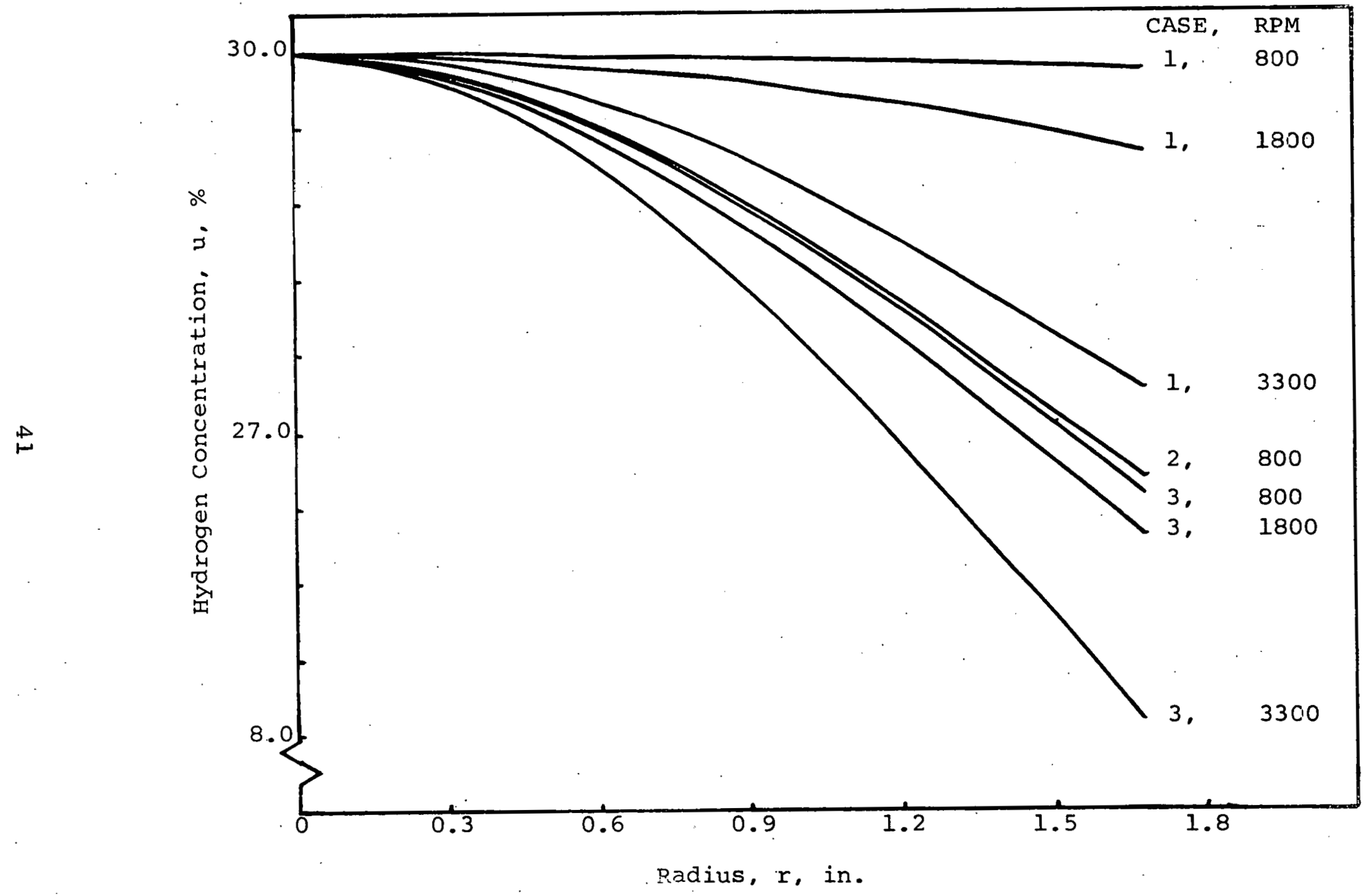

Figure 7 - Diffusion Model Equilibrium Hydrogen Concentration Distribution, $u_{0}=30 \%$. 


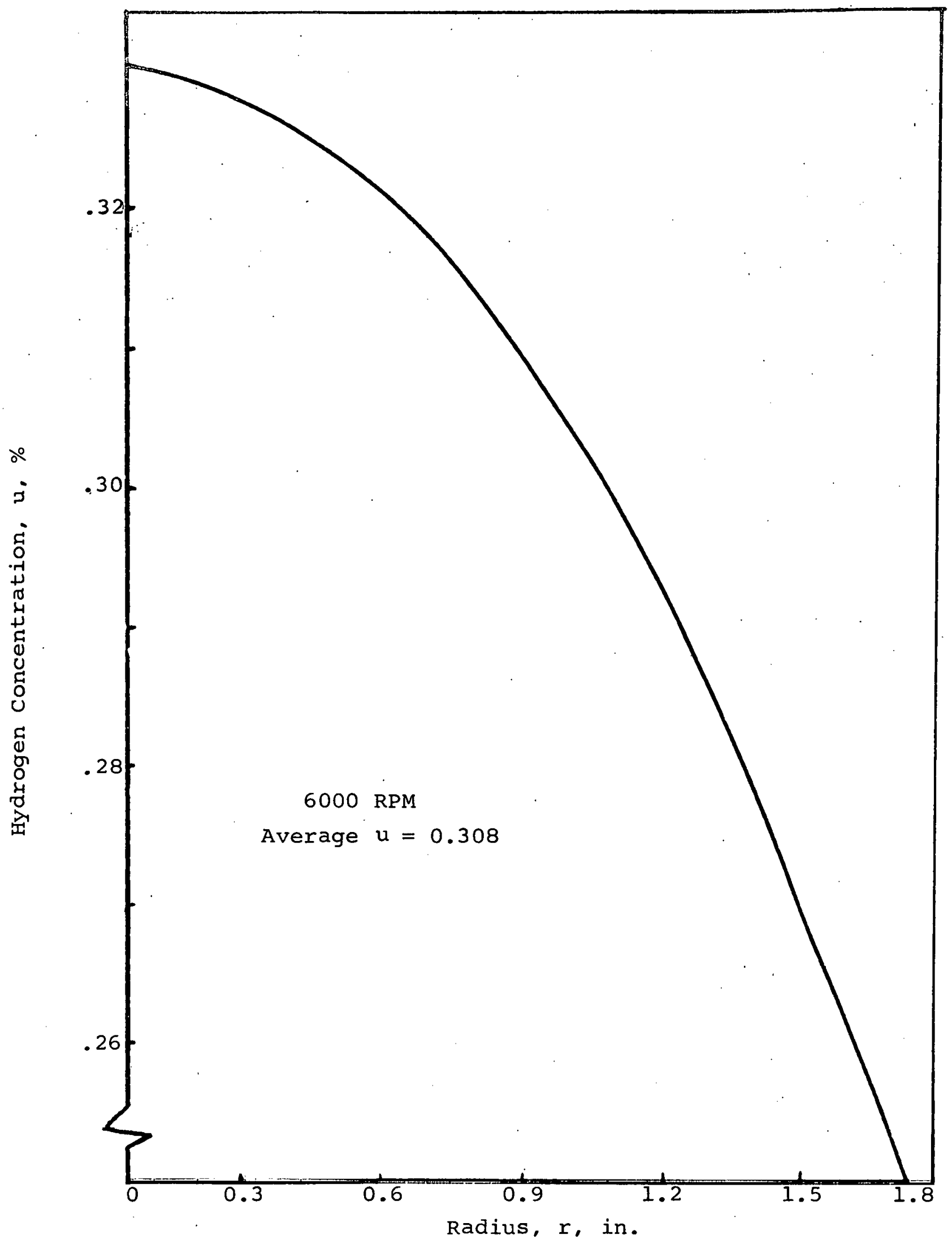

Figure 8 - Diffusion Model Equilibrium Hydrogen Concentration Distribution at High Speed, High Load. 


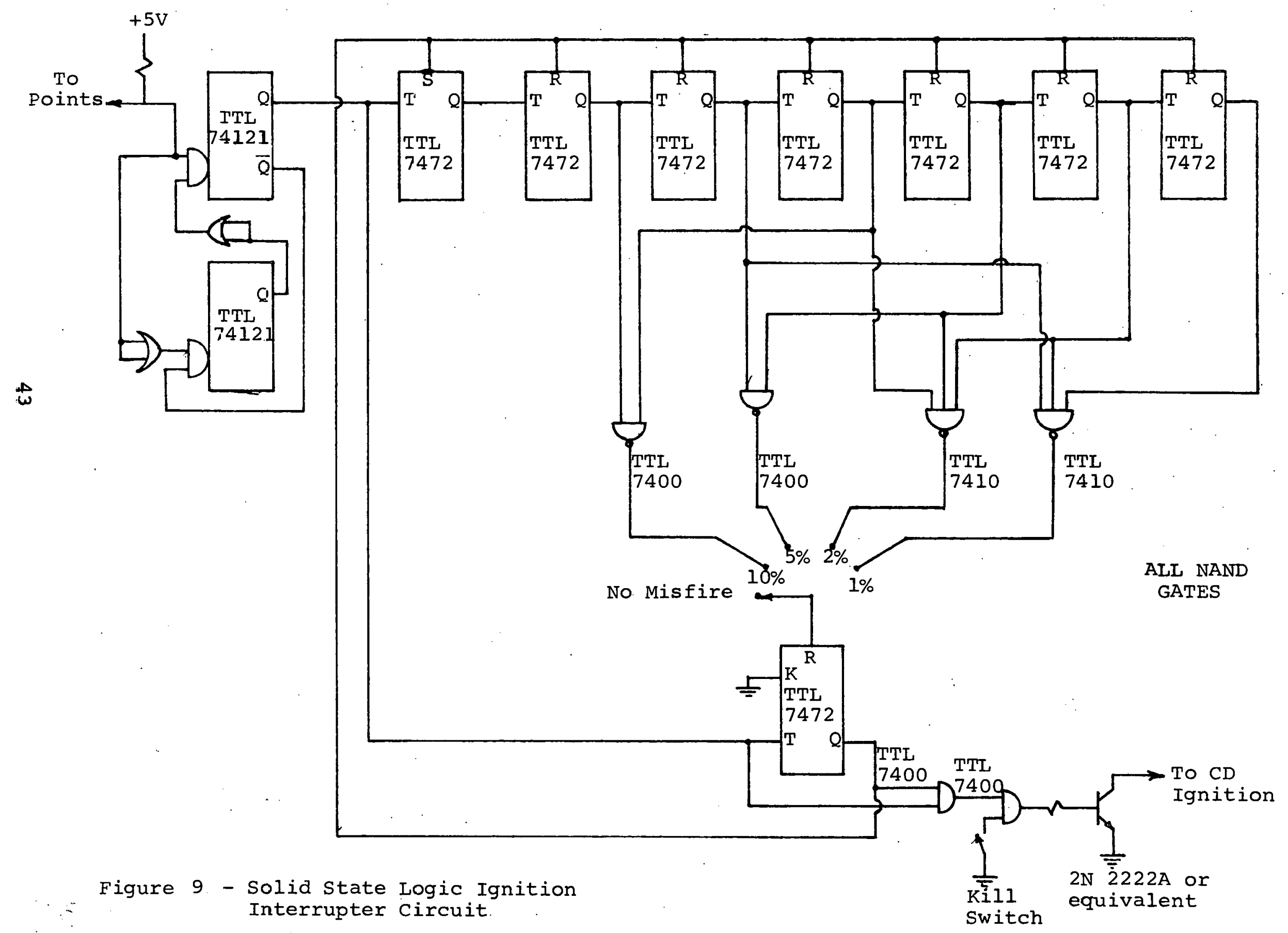

